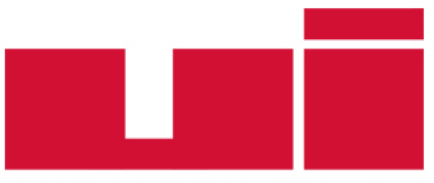

ULUUSLARARASIILIŞKiLER

Akademik Dergi

Yayın ilkeleri, izinler ve abonelik hakkında ayrıntılı bilgi:

E-mail: bilgi@uidergisi.com.tr

Web: www.uidergisi.com.tr

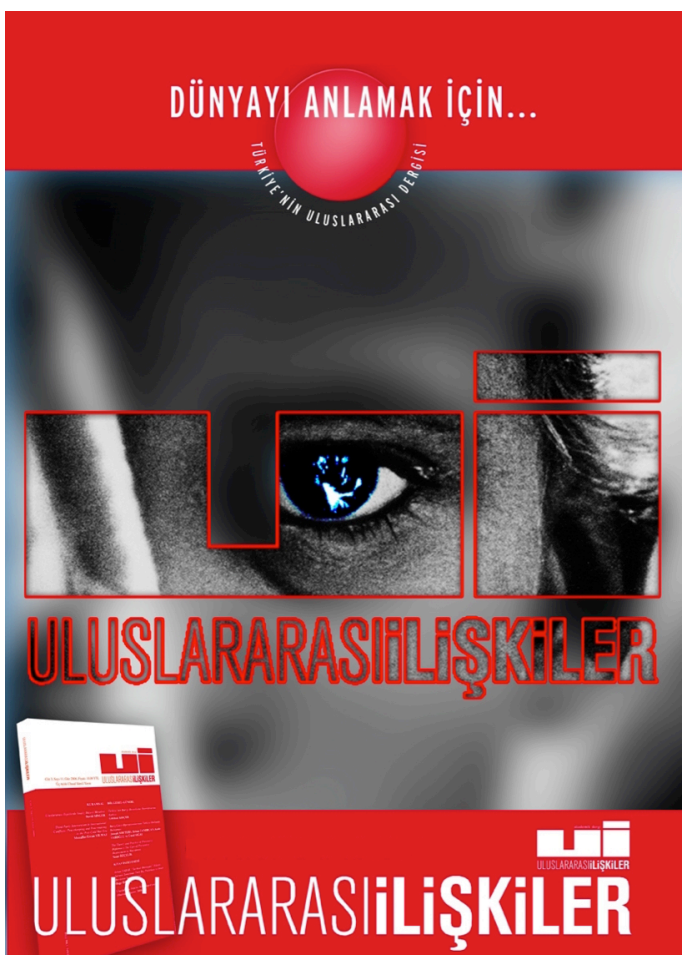

\title{
Güç ve Karşılıklı Bă̆ımlılı̆̆ı Yeniden Ele Almak
}

\author{
Robert O. KEOHANE* ve Joseph NYE, Jr.** \\ * Prof. Dr., Princeton Üniversitesi \\ ** Prof. Dr., Harvard Üniversitesi
}

Bu makaleye atıf için: Keohane, Robert O.; Nye, Jr., Joseph, "Güç ve Karşılıklı Bağımlılığı Yeniden Ele Almak", Uluslararası İlişkiler, Cilt 12, Sayı 46, s. 79-104.

$\mathrm{Bu}$ makalenin tüm hakları Uluslararası İlişkiler Konseyi Derneği'ne aittir. Önceden yazılı izin alınmadan hiç bir iletişim, kopyalama ya da yayın sistemi kullanılarak yeniden yayımlanamaz, çoğaltılamaz, dağıtılamaz, satılamaz veya herhangi bir şekilde kamunun ücretli/ücretsiz kullanımına sunulamaz. Akademik ve haber amaçlı kısa alıntılar bu kuralın dışındadır.

Aksi belirtilmediği sürece Uluslararası Illişkiler'de yayınlanan yazılarda belirtilen fikirler yalnızca yazarına/yazarlarına aittir. UİK Derneğini, editörleri ve diğer yazarları bağlamaz.

Uluslararası İlişkiler Konseyi Derneği | Uluslararası İlişkiler Dergisi

Web: www.uidergisi.com.tr | E- Posta: bilgi@uidergisi.com.tr 


\title{
Güç ve Karşılıklı Bağımlılı̆̆ı Yeniden Ele Almak
}

\author{
Robert O. KEOHANE \\ Prof. Dr., Princeton University, ABD.E-posta: rkeohane@princeton.edu \\ Joseph NYE, Jr. \\ Prof.Dr., Harvard University, ABD. joseph_nye@harvard.edu
}

\section{ÖZET}

Bu makalenin birinci bölümünde güç ve karşılıklı bağımlılık arasındaki ilişki, karmaşık karşılıklı bağımlılığın ideal türü ve uluslararası rejimlerdeki değişimlerin açıklamaları incelenir. İkinci bölümde, yazarlar kendi kavram ve teorilerini eleştirerek, gelecek çalışmalarda en fazla yarar sağlayacak argümanları belirlerler. Üçüncü ve dördüncü bölümler Güç ve Karş̧lıklı Bağımllık kitabında açık şekilde ifade edilmeyen, fakat gelecekteki araştırmalara 1şık tutacağına inanılan "sistemsel siyasal süreç” ve “öğrenme” gibi kavramlarla ilgili soruları gündeme getirmektedir.

Anahtar Kelimeler: Güç, Karşlıklı Bağımlılık, Sistemsel Siyasal Süreç, Öğrenme.

\section{Revisiting Power and Interdependence}

\begin{abstract}
The first section of this article examines the relationship between power and interdependence, the ideal type of complex interdependence, and explanations of changes in international regimes. In the second section, the authors critique their concepts and theories, and examine which elements of their argument have been most fruitful for later work. The third and fourth sections raise questions about concepts such as those of "systemic political processes" and "learning" that they did not explicate clearly in Power and Interdependence, but which they think suggests fruitful directions for future research.
\end{abstract}

Keywords: Power, Interdependence, Systemic Political Process, Learning.

* Misafir editörlerin notu: Makalenin İngilizce'den Türkçe’ye tercümesi Hande Dizdaroğlu (E-posta: handedizdaroglu@ gmail.com) tarafından yapılmıştır. Orijinal metin için bkz. Robert O. Keohane ve Joseph Nye, Jr. "Power and Interdependence Revisited”, International Organization, Cilt 41, No.4, 1987, s.725-753. Makalenin telif hakkı Cambridge University Press tarafından yayınlanan International Organization'a aittir. Makalenin Türkçe'ye çevrilmesine izin veren Cambridge University Press'e teşekkür ederiz. Özel sayının formatına uyması amacıyla, makaleye orijinal metinde olmayan kısa özet, anahtar kelimeler ve kaynakça eklenmiş; dipnotlar Uluslararası İlişkiler Dergisi'nin atıf sistemine uyarlanmıştır. Metin içindeki tüm italik ifadeler yazarlara aittir. Yazarlar orijinal makaleye şu dipnotla başlamaktadırlar: "Bu makalenin önceki versiyonlarına yazılı katkılarından ötürü David A. Baldwin, James A. Caporaso, Alexander L. George, Ernst B. Haas, Stephan Haggard, Stanley Hoffmann, Harold K. Jacobson, Peter J. Katzenstein, Stephen Krasner, David Laitin, Helen Milner, Andy Moravcsik, M. J. Peterson, Steve Solnick'a; International Organization dergisinin hakemine ve sözlü katkılarından ötürü Columbia Üniversitesi Savaş ve Barış Araştırmaları Merkezi üyelerine ve Harvard Üniversitesi Bahar 1987 Uluslararası İlişkiler Saha Seminerine teşekkürlerimizi sunarız." 
Güç ve Karşılıklı Bağımlılık'ı on yıl önce yayınlamıştık. ${ }^{1}$ On yıl bu kitabın yeniden okunması ve değerlendirilmesi ile katkı sağladığı araştırma programının gözden geçirilmesi için uygun bir zamandır. Böylelikle, karşılıklı bağımlılık siyasetine ilişkin akademik anlayışa derinlik ve zenginlik kazandırmayı ve gelecek on yılda uluslararası ilişkilerin yönelimlerine dair düşünceleri canlandırmayı ummaktayız. ${ }^{2}$

Dünya siyasetinde ve özellikle Amerika politikasında arada geçen yıllara damgasını vuran değişimler dikkate alındığında, bu tarz bir yeniden değerlendirme uygun olacaktır. Stanley J. Michalak’ın 1979'da bahsettiği gibi, yazarlar “benzetmeden kaçınsa da Güç ve Karşılıklı Bağımlılık, 1970'li yılların Uluslararası Politika kitabı olabilecektir.” ${ }^{3}$ Fakat 1980'lerin sonlarının bakış açısıyla dünya daha farklı gözükebilir: Zira 1970'ler karşılıklı bağımlılık yılları olarak nitelendirilirken, birçok gözlemci 1980’lerin temel özelliği olarak kuvvet kullanımı ve güvenlik kaygılarını dikkate alır. Gerçekten de, 1980'lerin 70'lere nazaran 50'li yıllarla daha çok benzeştiği ve Hans J. Morgenthau'nun çalışmasının dünya siyasetindeki güncel konularla Güç ve Karşılıklı Bağımlılık'tan daha fazla ilişkili olduğu görüşü bazı çevrelerde yaygındır.

1970’ler boyunca Amerikalılar Vietnam Savaşına tepki gösteriyordu; yumuşama dönemi nükleer silahlanma yarışının etkisini azaltmış ve petrol krizleri ile sabit döviz kurunun geçerli olduğu Bretton Woods sisteminin çökmesi dünya siyasal ekonomisindeki temel değişimleri yansıtmış gibiydi. "Yenilikçi” (modernist) yazarlar arasındaki temsili görüşe göre, "yükselen güçler, içinde çatışma ve işbirliği gibi baskın yapıların bulunmadığı küresel topluma -ulus devletlerin, yerel yönetimlerin, ulusötesi çıkarların ve toplulukların bireylerin desteği ve sadakatini kazanmak için rekabet içinde bulunduğu ve güç ilişkilerinin kaygan bir zemine oturduğu ortamda çatışmaların anlık pazarlıkla çözülmek zorunda olduğu bir poliarşi ye- doğru yönelmeye başlıyordu”."

1980’lere gelindiğinde, ABD'deki atmosfer Sovyetlerin Afganistan’ı işgali, İran'da rehinelerin ele geçirilmesi ve Sovyet stratejik kuvvetlerinin gelişiminin devamının etkisiyle değişmişti. Amerikan politikası Güney-Kuzey meseleleri ve çokuluslu kurumların faaliyetleri yerine Doğu-Batı çatışmasına odaklandı. Reagan yönetimi döneminde savunma bütçesi Soğuk Savaşın başlangıcından bu yana ilk kez beş yıl boyunca üst üste arttırıldı ve $\mathrm{ABD}$ aşırı güçsüz olmalarına rağmen Grenada ve Libya gibi devletlere karşı silahlı güç kullanma konusunda daha istekliydi. Silahların kontrolü azaltıldı ve nükleer güçlerin modernizasyonuna hız verildi.

1970’li ve 80’li yıllar arasındaki farklar kolaylıkla abartılabilir. Psikoloji ve siyasi atmosfer, güç kaynaklarının askeri ve ekonomik göstergelerinden daha fazla değişmiştir. Dünya ticaret ya da dünya üretim payları ile ölçüldüğünde ekonomik üretimdeki yayılma sürmektedir. Arz şoklarına yönelik kırılganlık durgun hammadde piyasasını bir süreliğine rahatlatsa da, finans ve ticaretteki hassas karşılıklı bağımlılık artmaya devam etmektedir. Buna ek olarak, bazı söylemlerin aksine, süper güçler arasındaki ilişkiler Soğuk Savaş yıllarına geri dönüş göstermez. İttifaklar sadece gevşek değildir, ayrıca süper güçler arasında silahlanma kontrolü ve diğer farklı konularda daha fazla temas vardır. Bize göre, bu

1 Boston, Little, Brown, 1977.

2 Her zaman önde gelen isimlerden olan Raymond Vernon, bu değerlendirme sürecini basımından on yıl sonra önemli eserlerinden Sovereignty at Bay başlıklı kitabına dayanarak kanıtlamış, eleştirilere cevap vermiş ve kendi eleştirilerini sunmuştur. Bkz. Raymond Vernon “Sovereignty at Bay Ten Years After," International Organization, Cilt 35, No.3, 1981, s.517-30. International Studies Notes 12'nin (Bahar 1986) yakın zamanda yayınlanan özel sayısında, James N. Rosenau, Kenneth E. Boulding, John H. Herz, William T. R. Fox ve Robert C. North kendi çalışmalarında bahsetmişlerdir.

3 Stanley J. Michalak, “Theoretical Perspectives for Understanding International Interdependence”, World Politics, Cilt 32, No.1, 1979, s.150.

4 Seyom Brown, New Forces in World Politics, Washington, D.C., Brookings Institution, 1974, s.186. 
sebeple, Güç ve Karşılıklı Bağımlılık'ta ortaya konulan analiz gelişmeler tarafından geçersiz hale getirilmemiştir. Asıl sorular eserin güncelliğini kaybetmesi ile değil, analitik ikna becerisi ile ilgilidir.

Bu makalenin birinci bölümü kitabın en önemli üç temasını incelemektedir: Güç ve karşılıklı bağımlılık arasındaki ilişki, karmaşık karşılıklı bağımlılığın ideal türleri ve uluslararası rejimdeki değişimlerin açıklamaları. İkinci bölümde, kendi kavram ve teorilerimizi eleştirmekte ve gelecek çalışmalarda argümanımızdaki hangi unsurların en yararlıları olacağını incelemekteyiz. Üçüncü ve dördüncü bölümler, Güç ve Karşılıklı Bağımlılık'ta açık şekilde ifade etmediğimiz, fakat gelecekteki araştırmalara ışık tutacağına inandığımız "sistemsel siyasal süreç” ve "öğrenme” gibi kavramlarla ilgili soruları gündeme getirmektedir.

\section{Güç ve Karşılıklı Bağımlıık’ın Temel Konuları}

Güç ve Karşılıklı Bă̆ımlılık'ta "siyasal gerçekçilik" kavramını, devlet davranışını "sürekli askeri çatışma tehdidi belirler” görüşünü kabul ederek tanımladık ve “1960’lar boyunca gerçekçi görüşü benimseyen birçok hevesli yazarın askeri-güvenlik kaygılarını merkeze almayan yeni konuların gelişimini algılama konusunda yavaş olduğu" (s.5) argümanını ileri sürdük. Derlemesini yaptığımız Ulusötesi İlişkiler ve Dünya Siyaseti'nde ise "günümüzün çok boyutlu ekonomik, sosyal ve ekolojik karşılıklı bağımlılığının” önemine vurgu yaptık (s. 4). ${ }^{5}$ Yine de, Güç ve Karşılıklı Bağımlılık önceki eserlerimizden ya da ekonomik karşılıklı bağımlılığı meşhur edenlerden çok daha farklı bir tona sahipti. "Bizim dönemimizi feodal çağların sona ermesinden beri dört yüzyıldır dünya siyasetine hakim olan teritoryal devletin ... çokuluslu şirketler, ulusötesi sosyal hareketler ve uluslararası örgütler gibi teritoryal-olmayan aktörler tarafından gölgede bırakılan dönem olarak gören yenilikçi yazarları eleştirdik (s.3). Bize göre, gerçekçi görüşü "silahlı kuvvetlerin modası geçmiş ve ekonomik karşılıklı bağımlılık ise tehlikesizdir gibi basit bir düşünce ile değiştirmek, eşit derecede, fakat farklı nitelikte vahim hatalara neden olacaktır” (s.5).

Kuvvet kullanımının dört koşula dayanarak büyük devletler için artan biçimde maliyetli olduğunu ileri sürdük: Nükleer tırmanma riskleri; fakir ya da güçsüz ülkelerdeki insanların direnişi; ekonomik hedeflere ulaşılması üzerindeki belirsiz ve büyük ihtimalle olumsuz etkiler ve kuvvet kullanımının insan hayatına mal olmasına karşı çıkan kamuoyu görüşü. Fakat, dördüncü koşulun ayrıca totaliter ya da otoriter hükümetlerin politikaları üzerinde çok az etki yarattığını belirttik ve "bölgesel çekişmelere dâhil olan küçük devletlerin ve devlet-dışı terörist grupların önceki zamanlara kıyasla kuvvet kullanımına daha kolay başvurabileceği” konusuna dikkat çektik. "Bu karşıt eğilimlerin kuvvet kullanımı üzerindeki kesin etkisi, askeri güce dayalı hiyerarşiyi yıpratmasıdır” (s.228).

Yeniden değerlendirme yaptığımızda, kuvvet kullanımının sistemsel kısıtları hakkındaki genel argümanlarımızın halen yerinde olduğunu düşünüyoruz. Nükleer silahların faydası, temelde diğerleri tarafından yapılabilecek saldırıları caydırma ile sınırlıdır. Hem Sovyetlerin Afganistan müdahalesindeki başarısızlığında, hem de ABD’nin İran'ın rehine almasına karşı tepkisinin zayıflığında görüldüğü gibi, halkların sosyal seferberliği büyük güçler üzerinde bir sınırlama oluşturmuştur. Reagan yönetimi Orta Amerika'da dahi, ideolojik taahhütlerine rağmen Amerikan kara kuvvetlerini kullanma konusunda temkinli davranmıştır. Eisenhower yönetiminin göreli olarak daha düşük maliyetli ve etkili olan İran (1953), Guatemala (1954) ve Lübnan (1958) müdahalelerini, Amerika’nın 1980’lerdeki İran, Nikaragua ve Lübnan'da karşılaştığı sorunlarla kıyaslayın. Grenada mini-devletindeki zayıf reji-

5 Robert O. Keohane ve Joseph S. Nye (der.), Transnational Relations and World Politics, Cambridge, Harvard University Press, 1972. 
me karşı kuvvet kullanımı ve Libya’ya karşı sınırlı hava saldırısı bu kuralı doğrulayan istisnaların ifşasıdır: Grenada esas itibarıyla güçsüzdür ve $\mathrm{ABD}$ Libya’ya karşı kara kuvvetlerinin kullanımını taahhüt etmekten kaçınmıştır. Bunun yanı sıra, küçük devletler ve teröristler tarafından kuvvet kullanımı yaptığımız tanıma uymaktadır ve Amerika’nın terörizme karşı güç kullanımının etkisi epey sınırlı kalmıştır.

Askeri güç kullanımındaki kısıtlamalara ilişkin argümanımız iktisadi karşılıklı bağımlılık siyaseti analizimizin temelini oluşturdu. $\mathrm{Bu}$ analiz, bünyesinde birbirinden açık bir şekilde ayıramadığımız üç temel konuyu barındırmaktadır:

1. Pazarlık teorisini temel alan karşılıklı bağımlılık siyasetinin güç merkezli analizi;

2. "Karmaşık karşılıklı bağımlılık” dediğimiz ideal türün ve onun kapsadığı süreçlerin etkisinin analizi;

3. "Karşılıklı bağımlılık ilişkilerini etkileyen yönetim düzenlemeleri setleri” (s.19) olarak tanımladığımız, uluslararası rejim değişikliklerini açıklama çabası.

Karşılıklı bağımlılığı bir güç kaynağı olarak asimetrik karşılıklı bağımlılık kavramı aracılığıyla güç ile ilişkilendiren karşılıklı bağımlılık analizimiz birinci bölümde geliştirildi. "Aktörlerin birbirleriyle ilişkilerinde etki imkânını büyük ölçüde sağlayanın” "karşılıklı bağımlılıktaki asimetriler" olduğun yazdık (s. 10-11, orijinalinde italiktir). Bu şekilde, gücün kaynağı olarak asimetrik karşılıklı bağımlılık kavramı, Albert Hirschman'ın Ulusal Güç ve Dış Ticaretin Yapısı'nda ${ }^{6}$ ve Kenneth Waltz' in "Ulusal Karşılıklı Bağımlılık Miti”’ başlıklı makalesinde açıkça görülebilir.

Analizlerimiz, karşılıklı bağımlılık ile gerçekçi ve yeni-gerçekçi analizler ile liberallerin endişeleri arasında bağ kurdu. Gerçekçi teoriyi liberal "karşılıklı bağımlılık” teorisine bir alternatif olarak görmekten ziyade, her ikisini birbirlerinin tamamlayıcıları olarak gördük. Bize göre bu yaklaşım analitik olarak meşrudur, çünkü gerçekçilik ve liberalizmin kökleri bireylerin dürtülerine tepki vererek kendi çıkarlarının peşinde koştuğu faydacı dünya yaklaşımı görüşüne dayanır. Her iki doktrin de siyaseti pazarlıklar tarafından simgelenen ekonomik ve siyasi bir değiş tokuş süreci olarak görmektedir. Daha geniş anlamda, hem gerçekçilik hem de liberalizm pek çok devlet davranışının rasyonel ya da akıllı faaliyet olarak yorumlanabileceği varsayımında uzlaşırlar. Dolayısıyla, gerçekçilik ve liberalizm siyasi eylemin doğasına dair farklı tanımları olan kıyas kabul etmez paradigmalar değildir. ${ }^{8}$

Buna rağmen, gerçekçi ve liberal teoriler birçok alanda birbirlerinden keskin biçimde farklılık gösterirler. Gerçekçi-liberal tartışması özellikle dünya siyasetinde aktörlerin amaçları ve içinde bulundukları çevrenin doğası gibi konulara odaklanır. Gerçekçilik devletlerin güç ve güvenlik talepleri ile devlet bekasına yönelik tehlikeleri vurgular. Bu nedenle askeri güç, gerçekçilik için dünya siyasetindeki en önemli güç kaynağıdır. Devletler en nihayetinde kendi kaynaklarına dayanmalı, ekonomik olarak yüksek maliyetli olsa dahi sistemdeki göreli konumlarını muhafaza etmelidirler. Liberalizm de devlet davranışını inceler, fakat diğer gruplara da dikkatini yöneltir. Liberal düşünürlere göre ekonomik dürtüler de güvenlik kaygıları kadar önemlidir. En azından, işbirliği için potansiyel alanlar genişlediğinden ve gücün rolü ile devletlerin uluslararası sistemdeki göreli güç konumlarına yaptıkları vurgu azaldığından cumhuriyetler arasında askeri tehditler önemsiz olabilir.

6 Albert Hirschman, National Power and Structure of Foreign Trade, Berkley, University of California Press, 1945.

7 Charles Kindleberger (der.), The International Cooperation, Cambridge, Mass., MIT Press, 1970.

8 Bu noktayı biraz farklı terimler kullanarak savunan güncel bir çalışma için bkz. K.J. Holsti, The Dividing Discipline: Hegemony and Diversity in International Theory, Winchester, Mass., Allen\& Unwin, 1985. 
Güç ve Karşılıklı Bağımlılık'taki gerçekçilik tartışması kasten tamamlanmadı. Gerçekçiliğin bazı esas varsayımlarının incelenmesi ve bunların karşılıklı bağımlılık siyasetinin analizine uygunluklarının değerlendirilmesinden daha az biçimde gerçekçi geleneğin açıklanması ile ilgilendik. K. J. Holsti’nin cümleleriyle ifade etmek gerekirse, bazı eleştirmenler bizi "eski yaklaşımları ya da modelleri kastettiklerinin dışındaki alanlara uygulamayı denemek", dolayısıyla "korkuluk icat etmek" (straw man) ile suçluyorlar. Stanley J. Michalak “korkuluğumuz” un (straw man) 'hasis' ve sinanması kolay olabileceğini, fakat gerçekçilikle ilişkisinin son derece kısıtlı olduğunu belirtmiştir.” Geleneksel bir yaklaşım olarak liberalizme vurgudan tamamıyla kaçınılmıştır: Bizim analizlerimizin kökleri açıkça liberalizmin ana varsayımları ile örtüşen karşılıklı bağımlılık teorisine dayansa da, kendimizi liberal geleneğe dâhil etmek gibi bir çabada bulunmadık. Bugünden bakıldığında, Ernst B. Haas ve diğerleri tarafından 1950’ler ve 1960’larda geliştirilen, fakat büyük ölçüde bölgesel bütünleşmenin analiziyle sınırlı kalan liberalizmin yeni-işlevselci (neofunctional) yanını kısmen genişletmeyi amaçlıyorduk. Bizim ortaya koyduğumuz teorinin bu versiyonu teleolojik argümanlardan kaçınmış, tamamen askeri ve iktisadi güç dağılımı ile devletin rolünü dikkate almıştır. ${ }^{10}$ Eğer fikirlerimizi gerçekçilik ve liberalizm gelenekleriyle ilişkileri bakımından konumlandırmakta daha açık olsaydık, müteakip bazı karışıklıkların önüne geçebilirdik.

Karşılıklı bağımlılık, devlet ve önemli devlet-dışı aktörlerin davranışlarının sistemin diğer aktörlerine getireceği yükten dolayı, siyasi stratejinin bazı klasik sorunlarını yaratır. Etkilenen bu aktörler, eğer kapasiteleri yeterliyse, kendilerine uyum yükümlülügünün dayatılmasından kaçınmak amacıyla siyasi bir tepki gösterecektir. Dış politika açısından bakıldığında, hükümetlerin karşı karşıya geldikleri sorun, özerkliklerini mümkün olduğunca korurken uluslararası ticaretten nasıl yarar sağlayacaklarına dairdir. Uluslararası sistem açısından değerlendirildiğinde ise sorun, hükümetlerin (ve devlet dışı aktörlerin) sistemin kendi çıkarları doğrultusunda manipülasyonunu amaçlayan rekabetçi çabalarına rağmen karşılıklı yarar getiren işbirliği kalıbının nasıl oluşturulacağı ve sürdürüleceğine ilişkindir. ${ }^{11}$

Karşılıklı bağımlılık siyaseti analizinde, karşılıklı bağımlılığın sonuçlarının otomatik olarak diğer konularda fayda sağlayacağı öngörüsünde bulunmadığımız gibi, işbirliğine muhakkak yol açacağını da vurgulamadık. Buradaki temel nokta, karşılıklı bağımlılığın gücü tamamen hükümsüzleştirdiği değildir; bilakis karşılıklı bağımlılık ve belli bir alandaki potansiyel güç kalıpları tıpkı bir madalyonun iki yüzü gibi birbiriyle yakından ilişkilidir. Bu sebeple biz sadece gerçekçi ve liberal bakış açılarını yan yana koymaya değil, onları bütünleşik bir analizle birbirleriyle bağlantılı hale getirmeye de çalıştık.

9 K.J.Holsti, “A New International Politics?”, International Organization, Cilt 32, No.2, 1978, s.525; Michalak, “Theoretical Perspectives,” s. 148. Hatanın kabulu ve gerçekçi ve yeni-gerçekçi bakış açılarının sistemsel şekilde ifade edilmeleri için, bkz. Robert O. Keohane, “Theory of World Politics: Structural Realism and Beyond,” Ada Finifter (der.), Political Science: The State of Discipline ,Washington, D.C., American Political Science Association, 1983, s.503-40, tekrar basimı Robert O. Keohane, Neorealism and Its Critics, New York, Columbia University Press, 1986, s.158-203. Keohane'nin daha sonraki çalışmasında, After Hegemony: Cooperation and Discourse in the World Political Economy, Princeton, N.J., Princeton University Press, 1984, siyasal gerçekçilik ile tutarlı önermeler üzerinde liberal kabul edilebilecek etkileri olan kurumların teorisini oluşturmayı amaçlar.

10 Entegrasyon teorisi ve karşılıklı bağımlılık teorileri arasındaki bağlantı hakkındaki görüşlerimiz için, bkz. "International Interdependence and Integation”, Fred I. Greenstein and Nelson W. Polsby (der.), Handbook of Political Science, Cilt 8, Reading, Mass., Addison-Wesly, 1975, s.363-414. Karl Deutsch'un bölgesel entegrasyon çalışmaları Haas'inkiler kadar önemlidir. 1975 yılındaki makalemizde ifade ettiğimiz gibi analizimiz Haas'ın yeni işlevselcilik (neofunctionalism) çalışmalarına teşekkürü borç bilmektedir.

11 Bu duruşun aksine, Holsti karşılıklı bağımlılı̆̆ın sorun odaklı olmadığını ifade eder: "Karşılıklı bağımlılık olgusu yüzyıllar önce alanımızın oluşumuna yol açan savaş, barış, düzen ve güce dair kaygıda olduğu gibi, ciddi olarak dikkate alınmadan önce bir soruna neden olmalıdır” (Holsti, The Dividing Discipline, s.47). 
David Baldwin’in de daha sonra gözlemlediği üzere, "uluslararası değişim ilişkilerinde her konu-alanı kapsayacak şekilde ayrı bir teorinin geliştirilmesi gerekmemelidir."12

İkinci bölümde tanıtılan "karmaşık karşılıklı bağımlılık” kavramı, bizim karşılıklı bağımlılığın pazarlık analizinde hissettiğimiz tatminsizliği ve onun yetersiz gerçekçi varsayımlarına bölgesel bütünleşme teorilerinden bazı katkılar sunma çabamızı yansıtmaktadır. İkinci bölümde kullanılan "karmaşık karşılıklı bağımlılık” kavramının birinci bölümdeki "karşılıklı bağımlılık” kavramından çok farklı olduğunu anlamak son derece önemlidir. Karşılıklı bağımlılık, "ülkeler ya da farklı ülkelerdeki aktörler arasında karşılıklı etkiler eliyle belirlenen durumlar” anlamına gelen kapsayıcı bir terimdir (s.8). Bu Almanya ve İtalya arasındaki siyasi-ekonomik karşılıklı bağımlılık gibi, Sovyetler Birliği ve Birleşik Devletler arasındaki karşılıklı siyasi-askeri bağımlılık durumuna da uygulanabilir. Öte yandan "karmaşık karşılıklı bağımlılık”, uluslararası politikanın doğası hakkındaki gerçekçi varsayımlara dayanarak özetlediğimiz "gerçekçi”" ideal türe karşı kasten inşa edilen ideal türde bir uluslararası sistemdir. Karmaşık karşılıklı bağımlılık, birçok ülke arasında çoklu iletişim kanallarının toplumları birbirine bağlandığı (devletin bu bağlantıları elinde tutmadığı), sorunlar arasında hiyerarşinin bulunmadığı ve hükümetlerin birbirlerine karşı askeri güç kullanmadığı bir duruma işaret eder (s.24-25). İkinci bölüme "karmaşık karşılıklı bağımlılı̆̆ın dünya siyasi gerçekliğini tam olarak yansıttığını iddia etmediğimizi” belirterek başlıyoruz. "Aksine, bu ve gerçekçi bakış ideal türlerdir. Pek çok durum, bu iki aşırı ucun ortasinda bir yerlerdedir".

Sigara paketlerinin üzerinde sıklıkla görmezden gelinen etiketler gibi, ikinci bölümün başında yaptığımız uyarı, sanki karmaşık karşılıklı bağımlılık tartışmalarını farazi olarak yarattığımız değil de, gerçek dünya tanımımızmış gibi değerlendiren birçok okur tarafından unutuldu. Örneğin, Robert Art'ın karşılıklı bağımlılık teorisyenleri ile ilişkilendirdiği "ekonomik çıkarları iç içe geçen uluslar birbirlerine güç uygulayamaz ... çıkarlar birleştiğinde güç kullanımı faydasızdır...” argümanı liberal gelenekteki bazı düşünürleri tasvir ediyor olabilir, ama bizi değil. ${ }^{13}$ Aksine, birinci bölümde savunduğumuz gibi, "askeri gücün her zaman ekonomik güç üzerinde egemen olduğu ... yine de, gücün egemen türlerinin daha fazla kullanılmasının daha yüksek maliyetler getirdiği her zaman akılda tutulmalıdır. Dolayısıyla, maliyete kıyasla, belirli bir amaca ulaşmada askeri araçların ekonomik araçlardan daha etkili olacağının garantisi yoktur" (s. 16-17). Güç ve Karşılıklı Bağımlılık’ın başında "ne yenilikçi ne de gelenekselci bakışın karşılıklı bağımlılık siyasetinin anlaşılmasında yeterli çerçeveye sahip olmadığını” açıklamamıza rağmen (s. 4), J. Martin Rochester bizi "küreselci” ya da yenilikçi” olarak tanımlamaktadır. ${ }^{14}$ Yenilikçi duruşun aksine, karmaşık karşılıklı bağımlılığın mutlaka geleceğin öncüsü olduğuna dair görüşü reddediyoruz (s. 226-29). Aslında, Ulusötesi İlişkiler ve Dünya Siyaseti kitabında belirttiğimiz üzere, Güç ve Karşılıklı Bağımlılık araştırmamıza büyük ölçüde ulusötesi ilişkilerin önemini kanıtlamak için başlamış olsak da, incelemelerimiz çok daha nitelikli bir yargı üretmiştir.

Güç ve Karşılıklı Bağımlılık’’n ikinci bölümünde ele alındığı üzere dünya siyasetindeki tüm gerçek durumlar gerçekçi ve karmaşık karşılıklı bağımlılı̆̆ın ideal türleri arasındaki bir yerde bulunurlar. Bu sebeple, ikinci bölümdeki vurgumuz birinci bölümden epey farklıdır. Asimetrik karşılıklı bağımlılık

12 David A. Baldwin, "Interdependence and Power: A Conceptual Analysis", International Organization, Cilt 34, No.4, 1980, s.471-596.

13 Robert J. Art, “To What Ends Military Power?", International Security, Cilt 4, No.4, 1980, s.16-17. Prof. Art bizim görüşlerimizi yanlış ifade ettiğini açık şekilde belirttiği için övgüyü hak etmektedir. International Security, Cilt 4, No.4, 1980, s.189.

14 J. Martin Rochester, “The Rise and Fall of International Organizations as a Field of Study," International Organization, Cilt 40, No 4, 1986, Not 52, s. 792. Benzer bir hata Ray Maghroori ve Bennett Ramberg'de (der.) görülmüştür: Globalism Versus Realism: International Relations' Third Debate, Boulder, Westview Press, 1982. 
çerçevesinde müzakere çıktılarını yapısal olarak açılamak yerine bir durumun gerçekçilik-karmaşık karşılıklı bağımlılık çizgisindeki konumunun gözlemlediğimiz siyasal süreçleri açılamaya yardımcı olup olamayacağını soruyoruz. Her iki bölümün teorik dayanakları da birbirlerinden farklıdır: İkinci bölüm genel olarak liberal teoriye ve bazı kısımlarda bölgesel bütünleşme teorilerine dayanırken, birinci bölüm daha çok gözden geçirilmiş yeni-gerçekçi analizlere dayanmaktadır. Bütünleşme teorisinde olduğu gibi, karmaşık karşılıklı bağımlılık tartışmalarımız ulus-ötesi ve hükümet-ötesi ilişkilerle devletlerarası ilişkilere odaklanmakta ve eylemlerin yapısal açıklamaları yerine siyasi süreçlerdeki belli kalıpların aktör davranışlarını nasıl etkilediğini incelemektedir.

Güç ve Karşılıklı Bağımlılık'ı üçüncü ana teması, birinci bölümde "karşılıklı bağımlılık ilişkilerini etkileyen yönetim düzenlemeleri” (s.19) olarak tanımladığımız, uluslararası rejimleri ele almaktadır. Bizim kullandığımız uluslararası rejimler kavramı, 1975'de rejimleri “örgütsel güçler ve finansal taahhütlerle uyumlu karşılıklı beklentiler, genel kabul gören kural, düzenleme ve planlar kümesi” olarak tanımlayan John Ruggie'nin çalışmalarına dayanmaktadır. ${ }^{15}$ Susan Strange tarafından ortaya atılan iddianın aksine, bu kavram sosyal bilimciler tarafından bulunmamıştır; aksine kavramın uluslararası hukukta uzun bir geçmişi vardır. ${ }^{16}$

Güç ve Karşılıklı Bağımlılık'ın üçüncü bölümü kullandığımız uluslararası rejimler kavramını detaylandırmakta ve bu sistemdeki değişiklikleri anlamaya yarayacak dört taslak model önermektedir. Modellerden biri ekonomik ve teknolojik değişimlere dayanmaktadır. İki model yapısaldır: Biri sonuçları öngörebilmek için tamamen güç yapısını kullanmakta, diğeri sorun alanlarında güç dağılımına dayanmaktadır. Dördüncü model ise, ilişkiler, normlar ve örgütlerden oluşan ağların uluslararası rejim değişikliklerini açıklamaya yarayan önemli ve bağımsız faktörlerin içinde bulunduğu "uluslararası örgüt modeli"dir.

Güç ve Karşılıklı Bağımlılık'taki üç konu bazı açılardan birbirlerinden farklılık gösterir. Karşılıklı bağımlılık, karmaşık karşılıklı bağımlılık ve uluslararası rejimler kavramları benimsenmeksizin siyasi açıdan analiz edilebilir; uluslararası rejimler kavramının geçerliliği ise karmaşık karşılıklı bağımlılık kavramının gerçekliğin basitleştirebilmesi olarak kabulünü gerektirmez. Yine de, kavramlarımızı birbiriyle bağlantılandırmaya çalıştık. Bilhassa, rejim değişikliği kuramlarının genel yapısının açıklama gücü gerçekçilikle karşılaştırıldığında karmaşık karşılıklı bağımlılık koşullarında daha zayıftır (s.161). Buna karşılık, bizim argümanımızın bir noktaya kadar bölümlere "ayrıştırılabilir" olması nedeniyle, bazı bölümlerinin akademik tartışmalarda diğerlerinden daha başarılı olması şaşırtıcı değildir.

15 John Gerard Ruggie, "International Responses to Technology: Concepts and Trends”, International Organization, Cilt 29, No.3, 1975, s.569; ayrica bkz. Richard N. Cooper, "Prolegomena to the Choice of International Monetary System", International Organization, Cilt 29, No.1, 1975, s.64. Güç ve Karşılıklı Bağımlılık'ta Ruggie ve Cooper'ın çalışmalarına s.20'de yer verilmiştir.

16 Susan Strange, “Cave! Hic Dragones: A Critique of Regime Analysis”, International Organization, Cilt 36, No.2, 1982, tekrar basım Stephen D. Krasner (der.), International Regimes, Ithaca, N.Y., Cornell University Press, 1983, bu iddianın olduğu sayfa s.344. Yönetim terminolojisinin önceki kullanımları için bkz. Fernand de Visscher, Le Regime Nouveau des Détroits, Brussels, 1924, Extrait de la Révue de Droit internationale et de Legislation comparée, 1924, No.1-2; Lüksemburg ve Elbe nehirlerinin yönetimi konusu için, L. Oppenheim, International Law, H. Lauterpacht (der.), Cilt 1, 5. Baskı, New York, Longmans, Green, 1937, s.207, 366; David M. Leive, International Regulatory Regimes, Lexington, Mass., D.C. Heath, Lexington Books, 1976, 2 Cilt; aşağıdaki makaleleri de içeren diğer bir çok makale için American Journal of International Law: 1) William L. Butler, “The Legal Regime of Russian Territorial Waters,” Cilt 62 ,1968, s.51-77; 2) Richard Young, "The Legal Regime of the Deep-Sea Floor”, Cilt 62, 1968, s.641-53; 3) Leo J. Harris, "Diplomatic Privileges and Immunities: A New Regime is Soon to be Adopted by the United States," Cilt 62, 1968, s.98-113; 4) W. Michael Reisman, “The Regime of Straits and International Security”, Cilt 74, 1980, s.48-76; 5) John Norton Moore, "The Regime of Straits and the Third United Nations Conference on the Law of Sea", Cilt 74, 1980, s.77-121. 


\section{Güç ve Karşılıklı Bağımlılık Araştırma Programı: Bir Eleştiri}

Güç ve Karşılıklı Bağımlılık’ta müzakereye odaklanan karşılıklı bağımlılık kavramını kullanarak gerçekçilik ve liberalizmi bütünleştirmeye çalıştık. Gücün gerçeklerinin farkında olmamıza rağmen, ne askeri kuvvetleri gücün esas kaynağı olarak ne de güvenlik ve göreli konumu devletlerin temel amaçları olarak değerlendiriyoruz. İronik şekilde, ulusötesi ilişkiler hakkındaki önceki çalışmalarımız göz önüne alındığında, Güç ve Karşılıklı Bağımlılık'taki yapay analizin sonuçları ve Keohane'nin Hegemonya Sonrası örneğindeki gibi müteakip çalışmalar yeni-gerçekçiliği (neorealism) genişletmiş ve dünya siyaseti çalışmak için tutarlı alternatif bir teorik çerçeve yaratmak yerine yeni-gerçekçiliğe yeni kavramlar sunmuştur. Birinci bölümde tartışılan kavramlardan stratejik karşılıklı bağımlılık ve uluslararası rejimler gerçekçi teori ile en uyumlu ve Güç ve Karşılıklı Bağımlılık ile sonraki çalışmalarda derinlemesine gelişen kavramlardır. Karmaşık karşılıklı bağımlılık diğerlerine göre daha az gelişmiş ve daha az değer gören bir kavram olarak kalmıştır.

\section{Karşılıklı Bağımlılık ve Müzakere}

Karşılıklı bağımlılık analizimizde, dünya siyasetinde askeri hassasiyetlerdeki asimetrinin önemini sürdürdügünü vurguladık: "Ekonomik araçların ciddi bir askeri güç kullanımı karşısında tek başlarına etkisiz olmaları sebebiyle, askeri güç ekonomik güce hâkimdir” (s.16). Buna karşılık, askeri gücün kullanım maliyetinin yükselmesi nedeniyle, "hedeflenen amaca ulaşmada askeri araçların ekonomik araçlardan daha etkili olacağının bir garantisinin bulunmadığı” (s.17) görüşündeyiz.

Gücün rolünün azaltılması konusunda o kadar ihtiyatlı davrandık ki, David Baldwin bizi gerçekçi teoriyi reddetmede fazla ileri gitmediğimiz konusunda eleştirdi: "Keohane ve Nye güç kaynaklarının ikamesi konusunda açıkça şüpheci olmalarına rağmen, bunun yükünü güç kaynakları ikamesinin büyük ölçüde mümkün olduğunu belirtenlerin omuzlarına yüklemek konusunda isteksiz görünüyorlar....Sprouts ve Dahl nüfuz konusunda kapsamı açıkça belirtilmeyen herhangi bir açıklamayı pratikte anlamsız diye reddederken, Keohane ve Nye kendilerini 'gücün homojen tanımının yararını yeniden değerlendirmeye ihtiyaç duyabiliriz' şeklindeki ifade ile sınırlandırmaktadır." Baldwin’in “askeri gücün etkinliğini bir güç kaynağı olarak zaman zaman abarttığımız" ${ }^{17}$ yönünde eleştirileri de mevcuttur.

Baldwin, birçok arkadaşımız aksini arzu etse de, Güç ve Karşılıklı Bağımlılık’ "yenilikçi” manifesto olarak tanımlamamakta haklıydı. Tersine, kitap tutarlı şekilde, liberal ve gerçekçi teorilerin dogmatik varsayımlar olmadan ve hangi şartlar altında dünya siyasi gerçekliğini daha isabetli biçimde açıklayabileceklerini sormaktadır. Belirli bir durumda askeri gücün ne ölçüde önemli olduğu bizim için gerçekçi ya da yenilikçi dogmalar temelinde karar verilen bir hüküm değil, ampirik bir sorudur.

Müzakere teorisi bazı kavramlara netlik kazandırmış ve Hirschman’ın izinden sunduğumuz analize nitelik katmıştır. Baldwin’in çalışmaları davranışı başarılı şekilde "açılamak" için somut kaynakları kullanmanın sakıncaları ile yetersiz açıklamaları daha sonra onarabilmek için "yoğunluk", "beceri” ya da "liderlik" gibi etmenleri ortaya atmanın teorik tehlikelerini vurgulamaya yardımcı olmuştur. Harrison Wagner' in ortaya koyduğu gibi, birinin ortağına asimetrik olarak daha az bağımlı olması, ikili ilişkide karşı tarafı etkilemede ne yeterli ne de gereklidir. ${ }^{18}$ Gerekli değildir, çünkü belli bir konuda

17 David A. Baldwin, "Power Analysis and World Politics: New Trends Versus Old Tendencies”, World Politics, Cilt 31, No.2, 1979, s.169-181.

18 Harrison Wagner, “Economic Interdependence, Bargaining Power and Political Influence," basılmamış makale, Austin, University of Texas, 1986. 
yoğun tercihleri olan güçsüz aktör amaçlarını gerçekleştirmek için diğer konularda büyük ödünler verebilir. Yeterli değildir, denge durumunda, müzakere gücünü tamamen yansıtan anlaşma şartlarında, daha güçlü aktör bile belirli bir konuda eğer kazanımlarından daha fazla ödün vermesi gerekecekse etkisini kullanmayacaktır. Fakat biz hala asimetik karşılıklı bağımlılığın ikili ilişkilerde bir güç kaynağı olabileceğini düşünmekteyiz. Wagner'in de hassaslıkla belirttiği üzere, az bağımlı aktörler müzakerede daha bağımlı aktörlere nazaran daha az maliyetli tavizler verebilir. Ek olarak, güçlü ve zayıf aktörler arasındaki ilişkiler genel olarak iki taraflı müzakere olmaksızın, çok taraflı kural ya da sözleşmeler tarafından belirlenmektedir. Bu şartlar altında, kuralları çiğnemek ya da anlaşmaları değiştirmek isteyen güçlü devletler müzakere güçlerini atıl hale getirebilirler. ${ }^{19}$

Karşılıklı bağımlılıkta müzakere yaklaşımı beraberinde konular-arası-bağlantı (issue-linkage) hakkında soruları da doğurmaktadır, çünkü müzakere gücü atıl olmadığında bir konuda karşı tarafı etkilemeye çalışmak, bir başka konuda ödün vermek anlamına gelmektedir. Güç ve Karşılıklı Bağımlılık bu sorunu birinci bölüm yerine, karmaşık karşılıklı bağımlılığın tartışıldığı ikinci bölüme koyarak yanlış kategoride ele almıştır. Neticede, ABD ve Sovyetler Birliği ilişkisindeki gibi yüksek düzeyli konular-arası-bağlantı ekonomi ve güvenlik alanlarında gerçekleşmektedir. Bağlantı, karmaşık karşılıklı bağımlılık kadar gerçekçi uluslararası siyasetin de bir olgusudur. Aslında, ikinci bölümde belirttiğimiz üzere karmaşık karşılıklı bağımlılık koşullarında, bağlantılar gerçekçilikte olduğundan daha az etkili hale gelebilir (s.30-32).

Güç ve Karşılıklı Bağımlılık kitabındaki konular-arası-bağlantıya dair ayrıntılı analiz eksikliği, bazı gözlemci okuyucular açısından kitaptaki en tuhaf yan olmalıdır. Rejim değişikliği analizimiz gücün konuya özgü kaynaklarına odaklanmış ve konusal-yapısal teori'yi (issue-structure theory) geliştirmiştir. Arthur Stein'in belirttiği gibi, "bağlantı, uluslararası politikaya konu odaklı bakışta asıl analitik problemdir. Konuların ayrıştııılması bir noktadan sonra ileri gider... Çünkü bağlantı siyasetine uygun durumlar mevcuttur, uluslararası politikanın çalışılmasında konu-alan odaklı yaklaşımın geçerliliği de bağlama bağlıdır." ${ }^{20}$ Konunun önemine rağmen, hangi durumlarda bağlantının ortaya çıkacağını belirleyen bağlantı teorisi oluşturma konusunda başarısız olduk. Karmaşık karşılıklı bağımlılık şartları altında özellikle zayıf devletler tarafından çeşitli bağlantılar oluşturulabileceğini savunduk, (s.122-24) fakat konuyu orada bıraktık. Bu çabalanmadığı için değildi: Aslında konu hakkında taslak bir bölüm hazırladık, fakat bu çalışmaları belirsiz genellemeler ve açıklayıcı anekdotlardan ibaret hale geldiğinden çöpe atmaya karar verdik.

Bu konuda 1977'den beri önemli ilerlemeler kaydedildi. İlk olarak, Kenneth Oye, Ernst Haas ve Arthur Stein analiz için çok teferruatlı bölümler içeren bağlantı tipolojileri geliştirdiler. Özellikle ilgili olanlar Haas'ın taktiksel, parçalı ve esas konular arasında bağlantı şeklindeki üçlü ayırımı ve Oye’nin "şantaj” (birini yapmak istemediği bir konuda tehdit etme) ve "karşılıklı iltifat" (karşılıklı uzlaşma önermek) arasındaki ayrımıdır. Oye’nin ayrımı, mecburi ve tehdit kaynaklı bağlantı konularında Stein'in ayırımı ile paralellik gösterir. Her ikisi de Thomas Schelling'in taahhüt ve tehdit ayrımını hatırlatmaktadır: "Taahhüt gerçekleştiğinde, tehdit ise başarısız olduğunda maliyetlidir." 1

19 Uluslararası para sisteminde 1971'deki değişime dair analizlerimiz bu noktayı açıklamaktadır. Biz Amerika’nın zayıflığını vurgulamadık, Henry Aubrey'nin şu sözü ile ABD’nin konumunun gücünün altını çizdik: "Kredi veren kimsenin ABD üzerindeki etkisi Amerika’nın oyunu eski kural ve ilkelere göre oynamak isteyip istemediğine bağlıdır.” Power and Interdependence, s.140.

20 Arthur A. Stein, “The Politcs of Linkage”, World Politics, Cilt 33, No.1, 1980, s.81.

21 Thomas Schelling, The Strategy of Conflict, New York, Oxford University Press, 1960, s.177. Oye'nin bağlantı tartışmaları Kenneth A. Oye, Donald Rothchild ve Robert J. Lieber, Eagle Entangled: U.S. Foreign Policy in a Complex World, New York, Longman, 1979 eserinin giriş kısmında yer almaktadır, özellikle s.13-17; ayrıca bkz. Ernst B. Haas, "Why Collaborate? Issue-Linkage and International Regimes”, World Politics, Cilt 32, No.3, 1980, s.357-402. 
Konular-arası-bağlantı hakkındaki diğer çalışmalar, ekonomik ya da kamusal tercih yaklaşımının konular-arası-bağlantıya özenle uygulanmasıyla tipolojinin ötesine geçmiştir. Bu iddianın temel katkısı, konular-arası-bağlantının iktisadi takas gibi olmasıdır: Bir noktaya kadar biri kıt kaynak bol olanla değiştirilerek diğerinin faydası arttırabilir. Robert E. Tollison ve Thomas E. Willett 1979'da bu etki hakkında öncü bir makale yazdılar, James Sebenius ise bağlantı sorunlarının hangi şartlar altında karşılıklı yarar sağlayan müzakere için yeni olasılıklar yaratabileceğini belirlemek için oyun teorisini ve Deniz Hukuku Müzakereleri analizini kullandı. ${ }^{22}$ Tollison, Willett ve Sebenius akılcı tercih yaklaşımını kullanarak, konular-arası-bağlantının temel koşullarını rasyonel-tercih kapsamında anlamak için bir çerçeve oluşturdular.

Bu ilerlemenin iki-aktörlü basit modeller kullanma pahasına yapıldığı belirtilmelidir. Yine de, dünya siyasetindeki konular-arası-bağlantının temel özelliklerinden biri devletler içi olduğu kadar devletlerarası mücadeleleri de kapsamasıdır. Bir hükümet X konusunu Y konusuna bağlayarak bir kazanç sağlamak istiyorsa, bu aslında Y'deki bazı iyi şeyleri X'dekiler için değiştirmektedir. Örneğin, eğer nükleer yayılmayı durdurmak isteyen bir hükümet muhtemel nükleer yayılmayı gerçekleştirecek devleti nükleer santralde kullanacağı teçhizatın gönderilmesini engelleme konusunda tehdit ediyorsa, o devlet ihracatını genişletme hedefini nükleer yayılmayı durdurma hedefi için feda ediyordur. $\mathrm{Bu}$ politikanın ihracat artışı göreviyle sorumlu olan devlet birimleri tarafından hiç hoş karşılanmayacağı açıktır. Gerçekten de, bu politika konusunda hükümet-içi bir çekişme oluşması olasıdır, hatta bu durum bazı şartlarda hükümetler-ötesi koalisyonlar için de sorun haline gelebilir. Bağlantı hakkındaki gelecek çalışmalar, akılcı-tercih yaklaşımının analitik kesinliği ile genellikle dünya siyasetinde konulararası-bağlantıya eşlik eden karmaşık çok-taraflı oyunun katkılarını birleştirmelidir. ${ }^{23}$

Güç ve Karşılıklı Bă̆ımlılık kitabının karşılıklı bağımlılık ve müzakere çalışmalarına en büyük katkısı, karşılıklı bağımlılık siyaseti analizlerinin teferruatlı bir müzakere kavramsallaştırması gerektirdiğinin ve ekonomik karşılıklı bağımlılık kalıpları ile güç arasında karşılıklı etkinin bulunduğunun vurgulanmasıdır. Dünya siyaseti anlayışımızı geliştirecek şekilde başarılı bir bağlantı teorisi geliştiremedik. Onun yerine, siyasi-ekonomik etkileşimler ve askeri-siyasi çatışma kalıpları arasındaki ilişkileri dikkate alarak, yeni-gerçekçi araştırma programını basitçe biraz ileri taşıdık.

\section{Karmaşık Karşılıklı Bağımlılık}

Karmaşık karşılıklı bağımlılık kavramı açık bir şekilde gerçekçilikten daha liberaldir. Karmaşık karşlıklı bağımlılığı gerçekçiliğin güç ve yapı kavramlarıyla birleştirmek gibi bir girişimde bulunmadık. Aksine, karmaşık karşılıklı bağımlılık kavramını gerçekçiliğin ideal-tipik dünya siyaseti görüşüne karşı geliştirdik. Çünkü net bir şekilde karmaşık karşılıklı bağımlılığın dünya siyasetinin yerinde bir tasvirinden ya da eğilim tahminlerinden ziyade ideal bir tür olduğu konusunda 1srar ettiğimiz için bunun güncel dünya siyasetine katkısı muğlâktır. ${ }^{24}$

22 Robert Tollison ve Thomas Willett, "An Economic Theory of Mutually Advantageous Issue Linkage in International Negotiations”, International Organization, Cilt 33, No.4, 1979, s.425-49; James Sebenius, Negotiating the Law of the Sea, Cambridge, Harvard University Press, 1984, özellikle bölüm 6; Sebenius, "Negotiation Arithmetic", International Organization, Cilt 37, No.2, 1983, s.281-316.

23 World Politics'in özel sayısındaki ampirik çalışmaların kısa tartışmaları için bkz. Robert Axelrod ve Robert O. Keohane, "Achieving Cooperation under Anarchy: Strategies and Institutions", World Politics, Cilt 39, No.1, 1986, özellikle s.239-243.

24 Güncel uluslararası ilişkiler teorisindeki felsefi jargona olan meyil göz önünde alındığında, bunu karmaşık karşılıklı bağımlılığın "ontolojik statüsü” olarak nitelemeliyiz. Fakat henüz kendimizi buna yaklaştıramadık. 
Karmaşık karşılıklı bağımlılığı bir teori olarak değil, gerçekçi görüşün temel varsayımları tersine döndürülseydi siyaset nasıl olurdu konulu bir düşünce deneyi olarak sürdürdük. Bu sebeple, yapabileceğimiz halde, liberal teoriden tam olarak yararlanmadık. Öyle yapmış olsaydık, belki de kavram çok daha gelişebilir ve daha kolay kavranabilirdi. Buna karşılık, karmaşık karşılıklı bağımlılığın siyasi süreçlerinin araştırmak üzere son derece kapsamlı ampirik incelemeler yaptık ve 1920-70 yılları arasında iki konu-alanını (okyanuslar ve uluslararası finans, bölüm 5) ve iki ülke ilişkisini (ABD-Kanada ve ABD-Avustralya, bölüm 7) yakından inceledik. Bu vakalar çifte karşılaştırma görevi gördü: Okyanuslar ve ABD-Kanada ilişkisinde karmaşık karşılıklı bağımlılığın izleri yoğunken; finans (hükümetler için siyasi-ekonomik merkezilikleri nedeniyle) ve $\mathrm{ABD}$-Avustralya için ise (mesafe ve güvenlik endişelerinin önceliğine bağlı olarak) karmaşık karşılıklı bağımlılığın daha az belirgindi.

Karmaşık karşılıklı bağımlılık uygulamamızın tamamlanmamış olması, korkarız ki kuramsal etkisinin büyük ölçüde göz ardı edilmesinde kısmen rol oynamıştır. Daha önce belirtildiği gibi, ikinci bölümdeki tartışmamız gerçekçilik ve karmaşık karşılıklı bağımlılık arasındaki süreklilik etrafında şekillenmiştir: Aslında, bu devamlılık içinde belirtilen belirli durumun konumu bizim analizimizin bağımsız değişkenini oluşturmaktadır. Bu bağımsız değişken ve bizim açıklamaya çalıştığımız durum arasındaki ilişki kısmen iç içe geçmiştir. Güç ve Karşılıklı Bağımlılık’ta, karmaşık karşılıklı bağımlılığın üç ana özelliği belirtilmiştir: 1)devletin siyasi amaçları durağan hiyerarşiler çerçevesinde belirlenmez, takasa tabiidir; 2)toplumlar arasındaki çoklu iletişim kanallarının varlığı siyasi araçların çeşitliliğini de arttırmaktadır, bu da dışişleri bakanlıklarının devletlerin dış ilişkilerini kontrol etme kabiliyetlerini sıkı bir biçimde kısıtlar; 3)askeri güç büyük ölçüde konu ile ilgisizdir. Güç ve Karşılıklı Bağımlılık’taki Tablo 2.1 (s.37) gerçekçilik koşulları ile karşılaştırıldığında karmaşık karşılıklı bağımlılık şartları altında farklılaşmasını beklediğimiz siyasi süreçlerin beş setini sıralamaktadır. Bunlar aktörlerin hedefleri, devlet politikası için kullanılan araçlar, gündem oluşturma, konular arasındaki bağlantılar ve uluslararası örgütlerin rollerini içerir.

Bu durumda yöntemsel bir sorun hemen karşımıza çıkar. Karmaşık karşılıklı bağımlılı̆ğ devlet politikasının hedef ve araçlarını baz alarak tanımladığımız için, hedef ve araçların bir durumun karmaşık karşılıklı bağımlılığa mı yoksa gerçekçiliğe mi yakın olduğunun derecesine bağlı olarak nasıl etkilendiklerine dair genel tartışmalar gereksiz tekrar yaratacaktır. Dolayısıyla, siyasi süreçlerle ilgili önermelerimiz konular-arası-bağlantı, gündem oluşumu ve uluslararası örgütlerin rolü ile sınırlı kalmalıdır. Daha önce gördüğümüz üzere, bağlantı tartışmaları gerçekçi dünyaya uygun olduğu kadar karmaşık karşılıklı bağımlılığa da uygun olduğundan, özde iki bağımlı değişkenimiz kaldı: Gündemdeki değişiklikler ve uluslararası örgütlerin rolleri. İdeal olarak, gündem değiştiren ve uluslararası örgütlerin önemli olmalarını sağlayan koşulları belirleyen koşullu açıklamaları yapmalıydık. Bu sorular hakkında gerçekte ne kadar yol kat edildi?

Beşinci bölüm her iki süreci de tartışmaktadır. Gündem değişikliğinin "tutarlı ve işlevsel olarak birbirine bağlı konu-alanlarda sistemin kötü idaresinden” (s.121) kaynaklandığını savunuyoruz. Buna karşılık, bir gözlemcinin bunun ne zaman ve hangi yönde olacağını akıllıca tahmin edebileceği bir gündem değişim modeli belirlemedik. Gündem değişiminin anlaşılması konusunda, Richard W. Mansbach ve John A. Vasquez, "köken, kriz, ritüelleştirme, uyuşukluk, karar verme ve otoriter bölüşüm gibi unsurları içeren konu döngüsü” hakkındaki görüşlerini sunarak son derece ilginç bir katkıda bulundular. ${ }^{25}$ Aşamalara ilişkin birçok modelde olduğu gibi, "sorun döngüsü teoriden çok analiz için

25 John A. Vasquez ve Richard W. Mansbach, “The Issue Cycle and Global Change”, International Organization, Cilt 37, No.2, 1983, s.257-79, s.274'ten alıntı. Ayrıca bkz. Mansbach ve Vasquez, Search of Theory: A New Paradigm for Global Politics, New York, Columbia University Press, 1981, özellikle bölüm 4. 
bir çerçeve gibidir” şeklindeki açıklamalarında da görüldüğü üzere, nedensel süreçler Mansbach ve Vasquez tarafından açıkça ortaya konulamamıştır. Yine de bu, Güç ve Karşılıklı Bağımlılık'taki gündem değişimi hakkındaki kısa gözlemlerin çok ötesine geçmektedir.

Kısmen "uluslararası örgüt modeli” çalışmamız, kısmen de daha önceki uluslararası örgütlere dair çalışmalarımız nedeniyle bu konuda söyleyecek çok sözümüz bulunmaktadır. ${ }^{26}$ Uluslararası örgütleri tanımlayıcı hukukun dayanak noktası olarak değil, siyasi bağlantıları kurumsallaştıran ve içerisinde hükümetler-ötesi politikanın koordinasyon ve koalisyonun yer alabileceği oluşumlar olarak gördük. Uluslararası örgütler, uluslararası finansal ilişkilerle kıyaslandığında, okyanus siyaseti bakımından devletlerin gündemlerinde ve devletlerin çıtılar üzerindeki tesirlerinde daha fazla etkiye sahiptirler. Aradaki on yılda, uluslararası örgütlerin kanun-yapıcı yerine kolaylaştırıcı oldukları görüşü benimsenmiştir. Bu tür örgütlerin sayısı arttı, bazılarının -Uluslararası Para Fonu gibi- faaliyet alanları genişledi, fakat bu örgütler gerçek ulusüstü kabiliyetler geliştirmek konusunda çok az çaba gösterdiler. Keohane'in Hegemonya Sonrası kitabı uluslararası örgütler hakkındaki bu görüşü daha geniş bir uluslararası rejimler teorisi ile birleştirmektedir ve uluslararası örgütlerin en güncel analizleri faaliyetlerini bu çerçevede değerlendirirler.

Dar kapsamlı bakış adına, Güç ve Karşılıklı Bağımlılık kitabındaki analizlerimizi uluslararası sistem düzeyi ile sınırladık: Bize göre bu "sadece uluslararası sistem hakkındaki bilgiye dayanarak ne kadar açıllama yapılabileceğini bilmek için” gerekliydi (s.ix). Yerel düzeydeki faktörlerin belirleyici gücünün önemini kabul ediyoruz, fakat öncesinde sistemsel güçleri açığa çıkarmaya çabalıyoruz. ${ }^{27} \mathrm{Bu}$ karar sonucunda, menfaatlerin bizim teorimizle açıklanacak şekilde ve diş etkiyle oluştuğunu görmek durumunda kaldık. Bu sebeple, iç politikanın kendisi ve uluslararası ilişkilerin iç politika üzerindeki -Peter Gourevitch'in sonradan "ikinci ters imge" olarak nitelediği- etkisi göz ardı edilmiştir. ${ }^{28} \mathrm{ABD}$ ve diğer ülkeler tarafından kişisel çıkarların tanımındaki değişiklik -hem okyanus siyaseti hem de finansal ilişkiler- vaka araştırmalarımızda da yeterli bir açıklama olmaksızın kendini göstermeye devam etmiştir.

Bu zorluğun bir örneği, karmaşık karşılıklı bağımlılığının ideal türünün finansal ve okyanus konu-alanına yakınlaştığı ölçüyü tanımlayan ve uygulanabilirliğin ikincisinde daha fazla olduğu şeklinde sonlanan beşinci bölümde karşımıza çıkmaktadır. Gerçekçi bakış açısına göre, bu kanıtlar karmaşık karşılıklı bağımlılık süreçlerinin devletler için büyük önem taşıyan para politikası gibi konularla ilgisiz oldukları değerlendirmesi yapılabilir. Ayrıca, birçok gözlemci okyanus konu-alanı konusunda karmaşık karşılıklı bağımlılık sürecinin 1977'den beri genişlemek yerine daralmakta olduğunu düşünmektedir (ABD’nin Deniz Hukuku Sözleşmesi'ni imzalamayı reddetmesi bu görüşü kuvvetlendirmiştir). Karmaşık karşılıklı bağımlılı̆̆ın önemsizliğinin hızlı bir şekilde reddedilmesi fazla basit olur. ABD’nin deniz yetki alanları ve deniz yatağı kaynaklarının paylaşımı konularında daralmadan yana orijinal duruşu, ABD Donanması tarafından güvenlik kaygıları ile belirlenmişti. Fakat donanmanın bu duruşu ulus-ötesi ve hükümetler-ötesi koalisyonlarca Deniz Hukuku Konferansları kapsamında

26 Özellikle bkz., Keohane ve Nye, “Transgovernmental Relations and International Organizations”, World Politics, Cilt 27, No.1, 1974, s.39-62.

27 Bir araştırma stratejisi olarak bu yaklaşım büyük ihtimalle akıllıcaydı, çünkü analizi betimsel karmaşıklık seviyesine indirmeden, yerel siyaset ve uluslararası sistemi kuramsal olarak birleştirmek çok zordur. Son dönemde devlet yapısı kavramını kullanarak bu boşluğu kapatma çabaları önemli bir ilerleme sağladı. Bkz., Peter J. Katzenstein (der.), Between Power and Plenty: Foreign Economic Policies of Advanced Industrialized States, Madison, University of Wisconsin Press, 1978; ve Peter J. Katzenstein, Small States in World Markets, Ithaca, N.Y., Cornell University Press, 1985.

28 Peter A. Gourevitch, “The Second Image Reversed”, International Organization, Cilt 32, No.4, 1978, s.881-912; Politics in Hard Times, Ithaca, N.Y., Cornell University Press, 1986. 
geri püskürtülmüştü. ABD antlaşmayı imzalamayı reddetmeden önce ulusal çıkarlar anlayışını tersine çevirdi. Gerçekçilerin ABD’nin anlaşmayı imzalamayı güvenlik çıkarlarına ilişkin "kişisel çıkarları” sebebi ile reddettiğini savunması, bu çıkarların nasıl belirlendiği ve yenilendiği sorularının cevaplarını da gerektirir.

Karmaşık karşılıklı bağımlılık devletlerin mevcut amaç ve araçları üzerinden belirlendiğinden, çıkar oluşumunun iç siyaseti hakkındaki teorileştirme başarısızlığımız, karmaşık karşılıklı bağımlılık siyaseti analizlerimizi ciddi şekilde etkilemiştir. Karmaşık karşılıklı bağımlılıktaki değişimi anlamak, ancak iç ve uluslararası politika kalıpları arasındaki ilişkilerin analizi ile anlaşılabilecek olan devletin hedeflerindeki önceliklerin değişimi kavramayı içermektedir. Ek olarak, "çoklu iletişim kanalları” özelliği devletlerin bütüncül aktör olmadıkları anlamına gelmektedir -bu da "iç" ve "sistemsel" nedir sorusu arasındaki keskin çizginin kırılmasıdır. Araştırma amaçları doğrultusunda sistem-birim ayrımını kabulümüzün karmaşık karşılıklı bağımlılığın daha derin analizi olanağını zayıflattığını görmek zor değildir. Birçokları tarafından yanlış anlaşılan ve bazılarına ilgi çekici gelen "askıda kalma" ifadesi ile karşılanan kavram, uluslararası ilişkiler öğrencileri tarafından kuramsal basitliği ile benimsenen sistemsel bakış açısını yumuşatmadan gelişme yetisine sahip değildi.

\section{Uluslararası Rejim Değişimi}

Uluslararası ilişkiler literatüründe uluslararası rejimler kavramının kabul edildiği zamanki heves, karmaşık karşılıklı bağımlılık kavramının göreli ihmali ile taban tabana zıttır. Uluslararası rejimler kavramı, açıklanması gereken önemli olguları tespit etmesi ve bunları bir grupta toplayabilmesi itibarıyla değerini kanıtlamıştır. John Ruggie’nin birçok konuda "kurumsallaşmış kitlesel davranış"29 olarak tanımladığı kalıpları belirlemede etiket görevi görmüştür. Hatta kapsamı uluslararası güvenlik sorunlarını analiz etmeyi dahi içerecek şekilde genişletilmiştir. ${ }^{30}$ Hiç şüphesiz, "rejimler” artık her yerdedir!

Güç ve Karşılıklı Bağımlılık her ne kadar uluslararası rejimler kavramından ilk bahseden eser olmasa da, sistemsel ampirik analizlerde nasıl kullanılabileceğini göstermiş ve böylece onun kural, kurum ve uygulama kümelerini içine alan tanımlayıcı bir kavram olarak yaygın bir şekilde kullanılmasını teşvik etmiştir. Ayrıca, rejim değişikliğini anlayabilmek için dört model geliştirmiştir. Son on yılda, rejimler üzerine geniş bir literatür Ruggie'nin öncülük ettiği ve bizim genişletmeye çalıştığımız analiz yöntemini takip etmiştir. Bu çalışmanın büyük bölümü uluslararası rejimlerin zayıflayışını Amerikan hegemonyasının son çeyrek yüzyıldaki çöküşü ile ilişkilendirerek, hegemonyacı istikrar teorisini test etmeye çalışmıştır. Bu çalışmanın sonucu, tüm yönler düşüldüğünde, hegemonyacı istikrar teorisinin geçerliliği hakkındaki şüphelerin artmasıdır. Fakat uluslararası rejimler literatürü hegemonyacı istikrar teorisini test etmekle sınırlı kalmamıştır: Uluslararası örgütler, iç siyaset ve seçkinler aracılığıyla öğrenme özellikleri ile göreli güç kapasitelerindeki değişimler, uluslararası rejimlerin doğasını ya da onlardaki değişimleri açıllayabilirler.

29 Ruggie, "International Responses to Technology".

30 Robert Jervis Concert of Europe rejimini 19.yy'da tanımladı; fakat güncel uluslararası ilişkiler tartışmalarında merkezi stratejik ilişki içindeki ABD ve Sovyetler Birliği ilişkilerinde bir rejim aradı fakat başarılı olamadı. Janice Gross Stein ve Joseph S. Nye daha dar kapsamlı faaliyet alanlarına odaklandılar ve güncel dünya siyasetinde anlamlı güvenlik rejimlerini keşfettiler. Bkz., Stein, "Detection and Defection: Security 'Regimes' and the Management of International Conflict”, International Journal, Cilt 40, No.4, 1985, s.599-627; ve Nye, “Nuclear Learning and U.S.-Soviet Security Regimes,” International Organization, Cilt 41, No.3, 1987. Ayrıca Roger K. Smith'in revize edilen makalesine bkz."'The Non-Proliferation Regime and International Relations”, International Organization, Cilt 41, No.2, 1987, s.253-82. Smith rejim teorisine bir çok farklı bakış açısından eleştiri getirmiştir. 
Son on yılda, uluslararası rejimler üzerine araştırmalar büyük bir gelişme göstermiştir. Uluslararası rejimlerin, uluslararası ilişkilerin belli bir alanındaki beklentilerin etrafında bütünleştiği ilkeler, kurallar, normlar ve prosedürler olarak tanımlanmasında büyük ölçüde fikir birliği sağlanmıştır. ${ }^{31} \mathrm{Bu}$ tanımı hayata geçirmede sorunlar vardır: Özellikle uluslararası rejim kavramı formel devletlerarası resmi anlaşmaların kurumsallaşmış sonuçlarını aştığında, rejim olan ve rejim olmayan durumlar arasındaki sınırlar belirsizleşmektedir. ${ }^{32}$ Fakat rejimler hakkındaki birçok ampirik çalışma devletlerarası resmi anlaşmaların sonuçları ile ilgilenmektedir ve bu nedenle bazen kavrama yöneltilen işlevsel belirsizlik suçlamalarından muaftır.

Tanım ve işlev ile ilgili sorunlar bir kenara bırakıldığında, geçen on yılda bu ampirik çalışmadan uluslararası rejimlerin neden ve nasıl değiştiği -özellikle de hangi şartlar altında işbirliğinin kolaylaştığı ve devletlerin rejim inşası ve kurallarını uygulama konusunda neden istekli olduğu- konularında pek çok şey öğrenilmiştir. ${ }^{33}$ Bundan başka, sadece Batılı ülkelerden değil Sovyetler Birliği’nden de politika yapıcılar uluslararası rejimler açısından uluslararası işbirliği hakkında düşünmeye ve konuşmaya başlamışlardır. ${ }^{34}$

Yine de, bizim uluslararası rejim anlayışımız ilkel kalmıştır. Uluslararası rejimlerin neden ve nasıl değiştiği konusunda 1977 'de olduğundan daha net bir fikrimiz olsa da, süreci açılayacak ikna edici teoriler şöyle dursun, iyi test edilmiş ampirik genellemeler dahi mevcut değildir. Modellerimize iç politikayı daha iyi aktaramadan bahsi geçen değişim teorilerine sahip olmamız da mümkün değil. Uluslararası rejimlerin doğasının yerel yapıları etkilemesi ve bunlardan etkilenmesi beklenir: Uluslararası kurumlar ile bir yanda müzakereler, diğer yanda iç politika arasındaki etki akışı kesinlikle karşılıklıdır. Sosyal bilimciler mikroekonomi temelinde biçimlendirilmiş sistemik teorileri kullanarak uluslararası rejimlerin işleyişinin kimi yönlerini anlayabilirlerse de, bizim iç siyaseti detaylı olarak incelemeden devletlerin tercihlerinin nasıl değiştiğini anlamamız mümkün görünmemektedir. Tercihleri dışsal faktör olarak gördüğümüz müddetçe, oluşturduğumuz teoriler devlet stratejilerindeki değişimleri ileriye taşıyacak kuvvetleri ve dolayısıyla uluslararası etkileşim kalıplarını içermeyecektir.

31 Krasner (der.), International Regimes, s.2.

32 Bakınız Stephan Haggard ve Beth Simmons, “Theories of International Regimes”, International Organization, Cilt 41, No.3, 1987.

33 Para, ticaret ve petrol konularının tartışması için bkz. Keohane, After Hegemony; ve Krasner'in International Regimes çalışmasındaki Charles Lipson, Jock A. Finlayson ve Mark Zacher ile Benjamin J. Cohen tarafından ticaret ve ödeme dengesi konularında yazılan makaleler. Ek olarak, International Organization dergisindeki makalelere bkz.: Antartika regimleri için M. J. Peterson, "Antarctica: The Last Great Land Rush", Cilt 34, No.3, 1980; nükleer artış için Joseph S. Nye, "Maintaining a Non- Proliferation Regime", Cilt 35, No.1, 1981 ve Roger K. Smith "The Non-Proliferation Regime”, Cilt 41, No.2, 1987; sivil havacilık için Christer Jonsson, "Sphere of Flying: The Politics of International Aviation”, Cilt 35, No 2, 1981, Üçüncü Dünya tartışmaları için Charles Lipson, “The International Organization of Third World Debt”, Cilt 35, No 4, 1981, uluslararası nakliyat için Alan W. Cafruny, "The Political Economy of International Shipping: Europe versus America”, Cilt 39, No 1, 1985; uluslararası meta rejimler için Mark Zacher, “Trade Gaps, Analytical Gaps: Regime Analysis and International Commodity Trade Regulation”, Cilt 41, No 2, 1987. Uluslararası rejimlerin gelişimi ya da sürekliliğini açıllamayı amaçlayan kitap uzunluğunda üç güncel çalışma: Charles Lipson, Standing Guard: Protecting Foreign Capital in the Nineteenth and Twentieth Centuries, Berkeley, University of California Press, 1985; Stephen D. Krasner, Structural Conflict: The Third World Against Global Liberalism, Berkeley, University of California Press, 1985; ve Vinod K. Aggarwal, Liberal Protectionism: The International Politics of Organized Textile Trade, Berkeley, University of California Press, 1985.

34 Örneğin, 3 Haziran 1986 günü Sovyetler Birinci Sekreteri Mikhail Gorbachev Birleşmiş Milletler Genel Sekreteri’ne gönderdiği bir mesajda "nükleer enerjinin güvenli gelişimi için gecikmeden bir uluslararası rejim oluşturulmasına pratik sebeplerden doğan ihtiyaç ortadadır” şeklinde ifade etmiştir. New York Times, 4 Haziran 1986, s.A12. Biz Sekreter Gorbachev'in rejimler dilini kullanmaya neyin sevk ettiğini bilmiyoruz, fakat Sovyet bilimciler 1970'lerdeki denizler hukuku konferansı ile alakalı olarak bu kavramın kullanılmaya başlandığını ifade etmişlerdir. Kişisel görüşmeler, Moskova, 1986. 
Uluslararası rejimlerin devlet davranışlarına etkilerini rejim değişikliğine kıyasla çok daha az biliyoruz. Gerçekten de, uluslararası rejim öğrencileri çoğu zaman rejimlerin fark yaratabileceğini, çünkü rejimlerin aktörlerin çıkar hesaplarını ya da kapasitelerini değiştirebildiklerini basit bir şekilde varsayarlar. ${ }^{35} \mathrm{Bu}$ iddia incelenmiş ancak titizlikle test edilmemiştir. Güç ve Karşılıklı Bağımlılık, "örgütsel bağımlı kabiliyetler” (s.55) kavramından yararlanarak rejimin kabiliyetleri nasıl değiştirebildiği konusunda bazı gözlemler yapmış; sonraki çalışmalar ise rejimlerin hükümetlerin kendi çıkarları üzerindeki etkilerine, dolayısıyla devlet stratejilerine odaklanmıştır. ${ }^{36} \mathrm{Bu}$ argümana göre, rejimin ilkeleri, kuralları ve kurumlarının stratejiler üzerinde iki çeşit etkisi vardır. İlk olarak, belirsizliği azaltarak ve bürokratlara meşru davranışlar ve siyaset yapıcılara gerçekleştirilebilir anlaşma kalıpları hakkında kılavuz olarak beklentilerin birleştiği bir odak noktası yaratabilir. Uzun vadede, devletlerin kendi çıkarlarını rejimin kurallarına uyacak şekilde tanımlamasında bile değişim gözlemlenebilir. İkinci olarak, rejimler bazı hareketleri yasaklayarak devletin davranışlarını kısıtlayabilirler. Rejimlerin yaptırım gücünün az olmasından dolayı, güçlü devletler her şeye rağmen izinsiz tedbirler alabilirler, fakat bunlar itibarlarına ve bundan dolayı gelecekte anlaşma yapma kabiliyetlerine mal olabilir.

Buna benzer argümanlar, rejimlerin devletlerin kendi çıkarlarını vurgulayan analitik bir çerçeve içinde algılanabileceği düşüncesinin altını çizmektedir: Devletler itibarlarını korumak için rejimlerin kurallarını ve normlarını uygulayabilirler. Fakat rejimle ilgili ne bu ne de diğer çalışmalar devlet çıkarları üzerindeki rejim etkisinin ne ölçüde ve hangi şartlarda dünya siyasetini değiştirmede etkili olacağını tasarlamıştır. Rejimlerin etkileri konusunda göreli olarak zayıf kalan algımız, gelecek araştırmalar için fırsat sunmaktadır. Bilhassa, politikaların rejim ilkelerini, kurallarını ve kurumlarını ne kadar yakından takip ettiğini anlamak için devletlerin davranışlarını izleyecek daha dikkatli ampirik çalışmaya ihtiyacımız var. Fakat bu sadece ilk adımdır; eğer dikkatimiz sistem düzeyinde kalmaya devam edecekse, bir araştırmacı için rejimin nedensel durumunu ortaya çıkarmak çok zor olabilir. Belki devletler rejim yokluğunda benzer politikalar takip etmişlerdir. Rejimler kendi etkilerinden bağımsız olarak çıkarları yansıtabilir.

Rejimlerin etkisini belirlemek için, rejim kurallarının yokluğunda ne tür stratejilerin uygulanabileceğini keşfetmek amacıyla içsel karar alma süreçlerine bakılmalıdır. Keohane'in "miyop öz çıkar” dediği ${ }^{37}$ rejim kurallarının hükümetlerin kendi çıkar (rejimden ayrı olarak) anlayışı ile çatıştığı durumlardaki sorunları tanımlamaya çalışabiliriz. Daha sonra rejim kurallarına dayanan itibar ya da başka dürtüler, bu kuralları çiğnemeye yönelik teşviklere ağır basar mı diye soracağız. Rejim kuralları ne kadar etkilidir? Analistlerin hükümetlerin (muhtemelen rejimlere olan saygılarını abartıp) kendi kendilerini haklı çıkaran retoriğinin ötesine geçerek kararları etkileyen faktörlere ulaşmaları ancak bu meselelerdeki iç tartışmaları inceleyerek mümkün olabilir. Eğer incelenen hükümetlerin rejim kurallarını ihlal etmek için ılımlıdan kapsamlıya uzanan bir yelpazede teşviklere sahip olduğu nispeten köklü uluslararası rejimleri ilgilendiren birkaç mesele üzerinde bu tarz araştırmalar yapılmış olsaydı, uluslararası rejimlerin tesiri hakkında daha çok fikir sahibi olabilirdik. Eğer araştırma belirtilen konualanında belli bir zaman dilimi içinde rejim kurallarının kapsamını güçlendirmek veya genişletmek amacıyla kararların nasıl alındığını açıklıyorsa, bu rejimlerin kendi büyümelerine yardımcı olduklarını

35 Stephen D. Krasner, "Regimes and the Limits of Realism: Regimes as Autonomous Variables”, Krasner (der.), International Regimes, New York, Cornell University Press, 1983, s.355-68.

36 Erken ve sezgisel bir girişim için bakınız Oran R. Young, Compliance and Public Authority, Washington, D.C., Institute for the Future, 1979.

37 Keohane, miyop öz çıkarları "hükümetlerin belli bir konuda, o konu diğerlerinden ayrıştırıldığında, alternatif yol haritasının göreli maliyet ve fayda algısı" olarak tanımlamaktadır. After Hegemony, s.99, orijinal versiyonda italiktir. 
görüşünün test edilmesine de yardımcı olur. Ayrıca bu uluslararası rejimler devletlerin zaman içinde kendi öz çıkarını değiştirmeye yardımcı olur mu sorusunun içyüzünü kavramaya katkı sağlar.

Açıkçası, ulusal kararlar ve uluslararası rejimler hakkında yapılan çalışmalar, her ne kadar açıkça bizim önerdiğimiz gibi tasarlanmasalar da, kuralları çiğnemek için önemli teşvikleri içeren durumlar karşısında rejimlerin göreli zayıflı̆̆ını ortaya koymaktadır. ${ }^{38}$ Diğer yandan, devletlerin çoğu zaman rejimlere itaat etmesi, rejimlerin gerçekten de bir koordinasyon sağlama görevi ifa ettiklerini akla getirir. Fakat bize devletlerin itibarını etkileme ya da diğer yollar vasıtasıyla gerçekleşen bu güdülerin değişiminde rejimlerin etkileri hakkında pek az şey söylerler. Farklı seviyelerde zorlamayı içeren durumlardaki etki hakkında daha iyi fikir sahibi olabilmemiz için, miyop öz çıkar bağlamında tanımlanmış, uluslararası rejim kararlarından caymaya ya da kurtulmaya sevk eden bu güdüleri, daha geniş anlamda inceleyen çalışmalara ihtiyacımız vardır. Şu ana kadar bu türde çok az çalışma yapılmıştır, ancak bu çizgide yürütülecek öncü bir araştırmanın etkisi azımsanmayacak boyutta olacaktır. ${ }^{39}$

Uluslararası rejimlerdeki değişimlerin incelenmesinde yapısal teoriler önemini sürdürmektedir: Buradaki basitleştirmeler öz çıkarların uluslararası kurumların oluşumu ve devamı ile uyum içinde olabileceğinin gösterilmesine yardım eder. Fakat rejim teorileri, bizim kurumlar olarak tanımladığımız düzenli uygulama kalıplarının da dâhil olduğu güç yapılarını ve siyasi süreçleri bünyesinde barındığından, yapısal teori ile aynı kefeye konulmamalıdır. Bu süreçler iç politika ile iç içe geçmiş durumdadır: Bir kez geniş bir kavram olan sistemsel teori kullanıldığında, bu teori tek başına zaman içinde uluslararası rejimlerde meydana gelen değişimleri ve bunların siyaset üzerindeki etkisini açıklamaya yeterli olmayacaktır. Bu sebeple, bizim Güç ve Karşılıklı Bağımlılık'ta geliştirmeye çalıştığımız sistemsel teorinin genişletilmiş süreç-odaklılık versiyonu ve yapısal teori tek başlarına yetersizdir. Araştırmacıların şu anda karşılaştıkları esas sorun, sistemsel teorinin süreç-odaklı versiyonu ile iç politika analizini, sistemsel teoriyi savunanların bir çekincesi olan teorik bütünlüğ̈ kaybetmeden nasıl bağdaştıracakları konusudur.

\section{Yapısal Teorinin Kısıtları: Sistemsel Siyasi Süreçler}

Her ne kadar iç politikanın öneminin farkında olsak da, Güç ve Karşılıklı Bağımlılık'ta daha incelikli ve gelişmiş bir uluslararası sistem anlayışıyla dünya siyaseti hakkında birçok şey öğrenebileceğimizi varsaydık. Sistemlerin iki boyutu olduğunu söyledik: Yapı ve süreç. Esasen, kabiliyetlerin birimler arasındaki dağılımına işaret etmek için "yapı” kavramını yeni-gerçekçi bakış açısıyla kullandık. ${ }^{40}$ Süreç etkileşim kalıplarına işaret etmektedir: Birimlerin birbirleri ile ilişki kurma yolları. Poker oyunu benzetmesine bakıldığında, yapı oyuncuların kartlarını ve fişlerini, süreç ise resmi kurallar, gayri resmi gelenekler ya da anlaşmalar arasındaki ilişkileri ve oyuncular arasındaki iletişim kalıplarını sembolize

38 Uluslararası para rejimi Bretton Woods sistemi çöküşü için, örneğin, bkz., Joanne Gowa, Closing the Gold Window: Domestic Politics and the End of Bretton Woods, Ithaca, N.Y., Cornell University Press, 1983 ve John S. Odell, U. S. International Monetary Policy: Markets, Power and Ideas as Sources of Change, Princeton, N.J., Princeton University Press, 1982. Multi-Fiber Düzenlemesi şemsiyesindeki tekstil kısıtlamalarında kural ihlali ve kanun boşlukları üzerine bkz. David Yoffie, Power and Protectionism: Strategies of the Newly Industrializing Countries, New York, Columbia University Press, 1983.

39 Abram Chayes'in Küba Füze Krizi’nde hukukun rolü konusundaki çalışması, uluslararası rejimler örneğindeki gibi uluslararası normların olmadığına dair iddia için bir istisnadır. Chayes rejim dilini kullanmamıştır, fakat Amerikan Devletleri Örgütü ve Birleşmiş Milletler Şartı’nın da dâhil olduğu birçok uluslararası uygulama ve anlaşmadaki gibi anlaşmazlıkların barışçıl yoldan çözümü için uluslararası normların etkilerini tartışmıştır. Bkz. Abram Chayes, The Cuban Missile Crisis and the Rule of Law, New York, Oxford University Press, 1974.

40 Kenneth N. Waltz, Theory of International Politics, Reading, Mass., Addison-Wesley, 1979. 
etmektedir. Oyuncuların olasılıkları hesaplama kabiliyetindeki çeşitlilik, rakibin elinin ya da blöf yapma gücünün birim ya da aktör düzeyinde olup olmadığı anlamını taşır.

Sistem içerisinde yer alan süreçler, sistemdeki başat birimlerin özelliklerinden ve kendi yap1sından etkilenirler. Devletlerin tercihleri onları belli stratejilere uygun hale getirir; sistemin yapısı bazı fırsatlar ve kısıtlamalar sunar. Devletin davranışlarını açıklayabilmek için hem yapı hem de tercihler hakkında bilgi sahibi olunması gerekmektir. Örneğin, 1886 ya da 1914 veya 1936'da Almanya'yı çevreleyen jeopolitik yapıyı bilmek yeterli değildir; bunun yanında Almanya'nın Bismarck'ın muhafazakâr çizgisini mi, Kaiser’in düşüncelerini mi, yoksa Hitler'in devrimci stratejisini mi izlediğini bilmek gerekir. Devlet tercihlerini ve sistem yapısını anlasak bile, sistemin uluslararası kuruluşların doğası, ulusötesi ve uluslararası etkileşimleri gibi diğer niteliklerini kavramadan devlet davranışlarını tam olarak açıllayamayabiliriz. ${ }^{41}$ Sistemsel süreçlerin analizi araştırmacıyı sistem ve birim özellikleri arasındaki etkileşimi daha yakından incelemeye götürür - örneğin, aktörlerin tercihleri ile çevrelerindeki firsat ve kısıtlar arasındaki etkileşim. Bu da, sistemsel süreçlere odaklanarak dikkatimizi iç politika ve uluslararası yapı arasındaki karşılıklı bağlantı ve geçirgenliğe yöneltmek anlamına gelir.

Açıç̧ası, uluslararası siyasi davranışta devletler arasındaki güç dağılımı ile açıklanamayan çok sayıda değişken vardır. Yeni-gerçekçiler bunu reddetmez, fakat tüm belirleyicileri birim seviyesinde ele alırlar. ${ }^{42}$ Hâlbuki bu yanıt tatmin edici değildir. Uluslararası karşılıklı bağımlılığın yoğunluğu veya uluslararası kuralların kurumsallaşma seviyesi gibi faktörler iç özellikleri temelinde devletten devlete değişmemektedir (demokratik süreçlerin içeride yürütülme seviyesi ya da yerel ekonomi politiğin kapitalist mi sosyalist mi olduğundan farklı şekilde); bu nedenle bunlar Waltz’n daha önceki tanımlamasına göre birim-seviyesindeki faktörler değillerdir. Ayrıca, tüm açıklanamayan ihtilafları birim seviyesine yüklemek teorinin gelişimi önünde engeldir. Bu durum, sadece yerel siyasi ve ekonomik düzenlemelere işaret eden birim seviyesindeki faktörleri uluslararası sistem seviyesindekiler ile karıştırarak analiz görevini karmaşık hale getirmekle kalmaz, ayrıca bazı yeni-gerçekçi analistlerin devlet davranışlarında yapısal olmayan belirleyiciler hakkında sistem düzeyinde teori oluşturma firsatını kaçırmalarına neden olur.

$\mathrm{Bu}$ devlet stratejilerini etkileyen yapısal olmayan sistemsel faktörler iki genel kategoriye ayr1labilir: 1)devlet davranışları için yapısal olmayan teşvikler ve 2) devletlerin iletişim ve işbirliği kabiliyetleri. Yapısal olmayan teşvikler fırsatları temsil etmekte ve aktörler arasındaki güç dağılımını etkilemeksizin kazanç ve maliyet ya da risk arasındaki beklenti oranlarını etkileyerek ulusal çıkarları değiştirmektedir. Örneğin, devletler arasındaki askeri güç kaynaklarının dağılımı bu teknolojik gelişmelerle değişmese de silahların tahrip gücündeki artış devletlerin savaşa girmemesi için bir teşvik nedenidir. Ya da nakliyat maliyetlerinde azalma ticaretten sağlanan kârları arttırabilir, böylelikle aktörlerin göreli müzakere gücünde ya da birim seviyesindeki farklılıklarda herhangi bir değişim olmaksızın ekonomide açıllık politikaları desteklenebilir.

İşbirliği ve iletişim kabiliyeti, çıkarların tanımlanması ve diğer devletlerle ilgili edinilen tek bilginin tercihleri ve ellerindeki güç kaynakları hakkında olduğu bir dünyada uygulanamayacak stratejilerin takibi için firsatlar yaratabilir. Nasıl ki Mahkûm İkilemi’nde (Prisoner's Dilemma) oyuncuların birbirleri ile iletişime geçmesi oyunun doğasını değiştiriyorsa, örgütler de devletlerin iletişim

41 Waltz'ın çalışmalarına getirilen diğer eleştiriler için bkz., John Gerard Ruggie, "Continuity and Transformation in the World Polity: Toward a Neorealist Synthesis”, World Politics, Cilt 35, No.2, 1983, s.261-85; tekrar basım Robert O. Keohane (der.), Neorealism and its Critics, New York, Columbia University Press, 1986, s.131-57. Bu etkiye dair genişletilmiş argüman Keohane, After Hegemony, özellikle 1, 4-7. bölümler.

42 Kenneth N. Waltz, "Response to My Critics," Keohane (der.), Neorealism and Its Critics, s.322-46. 
kabiliyetlerini artırır ve devlet idaresinin ortak diline katkı sağlayacak şekilde karşılıklı yarar getiren anlaşmaların yapılmasını sağlarlar; böylelikle sonuçları değiştirirler. ${ }^{43}$ Poker oyunu benzetmemize geri dönecek olursak, her oyuncunun önündeki fiş yığınının miktarı önemlidir, fakat oyunun doğası ve kurallarına uyup uymadıkları da önemlidir.

Liberaller geleneksel olarak sistemsel süreçlerin bu iki yönünü vurgulamıştır -yapısal olmayan teşvikler ile iletişim ve işbirliği kapasitelerindeki çeşitlilik. Örneğin, liberal teorisyenler (farklı seviyelerdeki gelişmişlikleri çerçevesinde) ticaret ve ekonomik teşviklerden sağlanan kazançların devlet davranışlarını değiştirebileceğini vurgulamışlardır. Benzer şekilde, liberal teorisyenler sıklıkla artan ulusötesi (ve hükümet-ötesi) bağlantıların davranış ve iletişim üzerindeki etkilerine değinmişlerdir. Ayrıca, tabii ki kurumların ve değerlerin rolü liberal teorinin önemli bir parçası olmuştur. Tüm bu kavramlar 1950’lerin sonları ve 1970'lerin başları arasındaki zamanda bütünleşme teorisinin önemli konularıdı. Bunlar uluslararası ilişkilerin sistemsel düşüncesinin zaruri bileşenleridir; "sistem” Waltz’un yaptığı hatada olduğu gibi sadece sistemin bir yönü olan sistem yapısı ile özdeştirilmemelidir.

Bu durum, liberallerin sistemsel süreçler üzerine düşüncede tekel oldukları anlamına gelmez. Örneğin, güç dağılımını değiştirmediklerinde bile, teknolojideki değişimler gerçekçi düşünce için merkezdedir. Ayrıca liberal teorinin ele aldığı tüm kavramların da sistemsel düzeye ait olduğu şeklinde bir iddiada bulunmuyoruz. Fakat uluslararası sistemi tanımlarken süreç düzeyini yapı kavramına eklememizin teorileştirme becerimizi zenginleştireceğini ifade ediyoruz. Süreç ve yap üzerindeki bu vurgu, bizi iki görüş arasındaki keskin ayrım yerine, gerçekçilik ve liberalizm sentezine ulaştırır. Yenigerçekçilik sistemsel teorinin yapısalcı düzeyi için uygundur; liberalizm ise süreç düzeyinde en verimlisidir. Biz bunları süreç ve yapıyı içine alan sistem düzeyinde bir teori içinde birleştirmeyi istedik.

Yeni gerçekçi ve liberal teorileri sentezleyen bu bakış açısı bir tekrar sorununu ortaya çıkarmıştır. Eğer bağımlı değişkenler muğlak şekilde "ulusların davranışları" olarak tanımlanmışsa ve sistem düzeyindeki süreç onların davranışları ise, bu noktada davranış sürece referans verilerek "açıklanırken” tekrar sorununun olduğu aşikârdır. Bunu önleyebilmek için, bağımlı değişkenler belli davranışlar için çok dikkatli şekilde tanımlanmalıdır. Ayrıca, süreç düzeyinde -yapısal olmayan teşvikleri değiştiren ve iletişim ile işbirliği kabiliyetlerini değiştiren faktörler bakımından- nedensel unsurların açıkça tanımlanmış tipolojilerine ihtiyaç vardır. Teknolojik değişimler, iktisadi karşılıklı bağımlılık ve konu yoğunluğu yapısal olmayan teşvikleri etkileyen güçler arasındadır. ${ }^{44}$ İletişim ve işbirliği kabiliyetini etkileyen unsurlar arasında uluslararası kuralların, normların ve kurumların özellikleri -"uluslararası rejimler”- çok önemlidir. Son olarak, bir yanda iletişim ve işbirliği kabiliyeti ile teşvikleri etkileyen güçleri birleştiren nedensel süreçler, diğer yandan davranış takip edilmelidir; sadece aradaki bağlantıyla yetinmemek gerekir. ${ }^{45}$

Herhangi bir sistem-düzeyli analiz ister istemez yarım kalacaktır. Bu makalede altını çizdiğimiz gibi, karmaşık karşılıklı bağımlılık gibi sistemsel süreçleri kavramak için iç politikanın karşılıklı bağımlılık ve rejim oluşturma kalıplarını nasıl etkilediğini bilmemiz gerekir. Bu, ekonomik karşılıklı bağım-

43 Dilbilgisi ve işbirliğini kolaylaştıran sistemler süreçler analojisi hakkında tartışmaları Hayward Alker, Jr'a borçluyuz.

44 Konu yoğunluğu, belirlenen siyasi alanda ortaya çıkan konuların sayısı ve önemi olarak tanımlanmıştır. Bkz. Robert O. Keohane, “The Demand for International Regimes”, International Organization, Cilt 36, No.2, 1982, yeniden basım Krasner (der.), International Regimes. Daha sonraki baskıda referans s.155'tedir.

45 "Süreç-takibi" metodu ile ilgili bkz., Alexander L. George ve Timothy J. McKeown, "Case Studies and Theories of Organizational Decision Making”, Advances in Information Processing in Organizations, Cilt 2, 1985, s.21-58; ya da Alexander L. George, "Case Studies and Theory Development: The Method of Structured, Focused Comparison", s.4368, Paul Gordon Lauren (der.), Diplomacy: New Approaches in History, Theory and Policy, New York, Free Press, 1979. 
lılık ile rejimlerin iç politikayı nasıl etkilediğinin karşılıklı olarak anlaşılmasını da zorunlu kılmaktadır. Yapısalcı teori ve bizim Güç ve Karşılıklı Bağımlılık'ta geliştirmeye çalıştığımız sistemik teorinin süreçyönelimli genişletilmiş versiyonu kendi başlarına yetersiz kalmışlardır.

Örneğin, devletlerin işbirliği ve iletişim kabiliyetlerini düşünün. Bu bir yandan onların etkileşimlerini yöneten kurallara uyup uymamasına bağlı olsa da, diğer yandan devletlerin izledikleri hedefleri etkilemektedir; bu hedefler de iç politikadan etkilenmektedir. Statükocu ve devrimci hedefler arasındaki klasik ayrım işbirliği kabiliyetini anlayabilmek ile ilişkilidir. ${ }^{46}$ Durağan ya da çalkantılı davranış kalıbının olup olmadığına karar verirken, devletlerin hedeflerini belirleme yöntemlerinin sistemin sürecini nasıl etkilediğine bakmalıyı. Fransız Devrimi’nin klasik 18. yüzyıl güç dengesi üzerindeki etkilerine benzer şekilde, hedeflerdeki değişimler tek bir devletin iç süreçlerinden kaynaklanabilir. Demokratikleşme ve milliyetçiliğin yayılmasının 19. yüzyıl güç dengesi üzerindeki etkileri gibi, aynı anda birçok devletin iç ve diş politika hedeflerini etkileyen ulusötesi süreçlerin sonucu olarak da ortaya çıkabilir. Eğer yapı mutlak anlamıyla tanımlanırsa, 19. yüzyıl Avrupa sistem yapısının çok kutuplu olarak tanımlanması doğrudur, fakat bu kavramın değişimi açıklayamaması sistem kavramında yapıya süreci eklemeyi gerekli kılmaktadır. ${ }^{47}$ Ek olarak, iletişim ve işbirliğinin sistemsel süreç boyutuna odaklanmak, sistem ve birim-düzeyindeki değişimler arasındaki etkileşime dikkat çekerek araştırma programlarını zenginleştirir.

Devlet hedeflerinin sistemsel süreçleri etkilediğine (veya tam tersi) dair endişe bizi algı ve öğrenme sorularına yeniden bakmaya yöneltir. Bunlar, yeni konular olarak karşımıza çıkmasa da, bazı gerçekçi argümanlara kayda değer istisnalar olarak muğlak bir teorik duruşları vardı. Hem yapıyı hem de süreci kapsayan daha zengin bir sistem kavramı geliştirmek, algı ve öğrenmeyi disiplinin merkezine yaklaştırır ve siyasi örgütler nasıl “öğreniyor” konusunda anlayışımızı derinleştirmenin önemini akla getirir.

\section{Algılar ve Öğrenme ${ }^{48}$}

Devlet tercihleri elitlerin çeşitli yollarla değişebilen çıkar algılamalarını yansıtır. Bunlardan en belirgini siyasi değişimdir. Seçim, darbe veya nesilsel devinim, belirli bir düşünceye sahip liderlerin tamamen farklı ulusal çıkar algılarına sahip liderlerle yer değiştirmesine yol açabilir. "Ulusal çıkar”daki değişim toplumun bütünündeki yeni duygusal veya bilişsel görüşü tamamen yansıtmayabilir. Liderlik, iç sorunlar veya dış politikadan bağımsız diğer nedenlerle değişebilir. Çıkarlar normatif değişimler yoluyla da yeniden tanımlanabilir. Bir dönem kabul gören uygulamalar ve çıkarlar, normatif değişim nedeniyle daha sonraki dönemlerde gerileyebilir, hatta gayrimeşru hale gelebilir. Kölelik ve kolonyalizme ilişkin değişen görüşler buna örnek gösterilebilir.

Ulusal çıkarlar aynı zamanda öğrenme yoluyla da değişebilir. En temel anlamıyla, öğrenme birinin düşüncelerinin yeni bilgilerle değiştirilmesi, bilgi veya becerilerin çalışma veya deneyimle geliş-

46 Aslında devrimci ve statüko arasında çeşitli hedefler vardır. Ayrıca, bu hedefler devletlerin elindeki araçlara göre şekillenebilir. Bkz. Barry Buzan, People, States and Fear, Chapel Hill, University of North Carolina Press, 1983.

47 Bu makalede açıklama yetersizliği yüzünden eleştirdiğimiz Kenneth N. Waltz, çift kutuplu-çok kutuplu ayrımını, siyasi yapı kavramını son derece dikkatli ve sistemik şekilde geliştirdiği Uluslararası Siyaset Teorisi çalışmasında anlatmaktadır. Güncel 19.yüzyıl tartışmaları için, bakınız Paul W. Schroeder, "The 19th Century International System: Changes in the Structure" World Politics, Cilt 39, No.1, 1986, s.1-26. Schroeder küçük devletleri korumak için geliştirilen normlara vurgu yapmaktadır. Onun “yapıdaki değişiklikler” dediği şey, Waltz’ın yapısal değişimleri olarak algılanmamalıdır ve biz onlardan uluslararası sistem sürecindeki değişimler olarak bahsetmekteyiz.

48 Bu bölümdeki konuları daha iyi kavramamıza yardımcı olan William Jarosz ve Lisa Martin’e değerli yorumları için minnettarız. 
tirilmesidir. $\mathrm{Bu}$, yeni inançların, ahlaki olarak üstün olmak bir yana, daha etkin politikalar doğurduğu fikrini içermediğinden eksik bir tanımdır. Bu tanımın avantajı öğrenmenin, inançlardaki bir dizi verili değişimin, her ne anlama gelirse gelsin, "daha etkin" politikalara yol açıp açmadığını analiz etmeden belirlenebilir olmasıdır.

Oysa bu "öğrenme”nin tek olası tanımı değildir. Gerçekte öğrenme birçok tanımı olan esnek bir kavramdır. Bu karışıklığın bir kaynağı, “öğrenme”nin birinin davranışındaki ahlaki niteliğin gelişimini ifade edebilmesi görüşünden kaynaklanmaktadır. Alışılagelmiş kullanımında, insanlar iyiliğin yanı sıra kötülük yapmayı da "öğrenebilir”: Yıldırım harekâtı düzenleme stratejisi, saldırı amaçlı nükleer silahlar yapmak ve yerleştirmek, soykırım uygulamak gibi. Öğrenmeyi tartışan sosyal bilimciler, bunu ahlaken gelişmiş bir hareketle tanımlamaya ihtiyaç duymamaktadırlar.

Daha ciddi bir karmaşa, sosyal bilimlerde öğrenmenin daha geniş bir tanımının bizim önerdiğimiz dar tanımla kolayca bir arada bulunamamasından kaynaklanmaktadır. Daha kapsamlı kullanımında, öğrenme, bir kişinin çevresiyle etkin şekilde başa çıkabilme yeteneğinin gelişmesini çağrıştırabilir. Çok basit genellemelerden "karmaşık, temelinde gerçekçi ilgi yatan bütünleşmiş anlayışa" ${ }^{49}$ kaymayla belirlenmiştir. Uluslararası ilişkiler teorilerinde öğrenmenin önemini savunan öncülerden Ernst B. Haas, uluslararası öğrenmenin devletlerin "stratejik karşılıklı bağımlılık durumunda içindeki bulundukları ağın farkına varmalarıyla” ${ }^{50}$ ortaya çıktığını kabul etmektedir. Öğrenme meydana geldiğinde, "yeni bilgi ulusal çıkarın içeriğini yeniden tanımlamak için kullanılır. İstenmeyen etkilerin sonucundaki yeni bilinçlenme genellikle amaca ulaşmada farklı ve daha etkin araçların kullanılmasına yol açar”. ${ }^{1}$

Eğer öğrenmeyi istenilen sonuca etkili ulaşma olarak tanımlarsak, araştırma için yeni zorluklar belirecektir. Uluslararası politika gibi karmaşık bir alanda, böyle bir öğrenme gerçekleşmiş olsa dahi, olaylardan bir süre sonra bile karara varamayabiliriz. Yanlış yorumlanan "tarihin dersleri” ve isabetsiz kıyaslamalar nedeniyle liderler çoğu kez amaçlarına ulaşmada başarısız olurlar. ${ }^{52}$ Harry S. Truman'ın Münih deneyiminden taarruzun nerede olduğuna bakılmaksızın durdurulması gerekmediğine dair öğrendiği ders, Haziran 1950'de Kuzey Kore Güney’e saldırdığında kendisini akıllı kararlar alma konusunda daha çok ya da az deneyimli mi yaptı? Amerikan siyaset-yapıcılarının Kore Savaşı süresince Çin'in müdahale tehlikesi hakkında öğrendiği dersler, Amerikan askeri kuvvetlerinin 1960 ortalarında Vietnam’a gönderilmesi sırasında kendilerini daha etkin karar vericiler haline mi getirdi? 1970'lerde silahların kontrolünü eleştirenler Sovyetlerin ABD stratejik silah sistemlerini kolayca taklit edemeyeceğini öğrendiğinde, Reagan yönetimi süresince Amerikan güvenliği ya da dünya barışının korunması konusunda daha çok ya da az deneyimli hale mi geldiler? Bu örneklerin her birinde, inanışlar deneyimlerin sonucu olarak değişti ve politika-yapıcılar içine düştükleri stratejik karşılıklı bağımlılık ağlarının daha çok farkına vardılar; fakat kazanılan değerli bilgi veya yeteneklerin kendilerinin daha etkili hareket etmelerini sağlayıp sağlamadığı tartışma konusu olarak kaldı.

Uluslararası ilişkilerde öğrenme üzerine bir araştırma yürütürken, öğrenmenin hangi tanımını kullandığımızı belirtmemiz gerekir. Her ne kadar öğrenme daha basit bir şekilde tanımlanabilirse de,

49 Llyod Etheredge, Can Governments Learn?, New York, Pergamon Press, s.143; ayrica "Government Learning: An Overview” Samuel Long (der.), Handbook of Political Behavior, Cilt 2 , New York, Plenum Press, 1981, s.73-161.

50 Ernst B. Haas, "Why We Still Need the United Nations: The Collective Management of International Conflict, 19451984", Policy Paper in International Affairs, No 26, Berkeley, Institute of International Studies, 1986, s.68.

51 Ernst B. Haas, "Why Collaborate? Issue-Linkage and International Regimes”, World Politics, Cilt 32, No.3, 1980 , s.390. Ayrica bkz. John D. Steinbruner, The Cybernetic Theory of Decision, Princeton, N.J., Princeton University Press, 1974 ve Robert Jervis, Perception and Misperception in International Politics, Princeton, N.J., Princeton University Press, 1976.

52 Richard Neustadt ve Ernest May, Thinking in Time, New York, Free Press, 1986. 
düşüncelerin yeni bilgiyle değişmesi şeklindeki dar tanımıyla başlamanın düşünmeyi daha anlaşılır hale getirdiğine inanıyoruz. Haas'ın belirttiği gibi, bu şekilde bir öğrenme stratejik karşılıklı bağımlılığın farkındalığını arttırmaktadır. Hangi koşullar altında öğrenmenin daha etkin şekilde hedefe ulaştıracağı, olması gerektiği gibi, tanımsal olandan ziyade daha sonra deneysel ve teorik bir soru haline gelmektedir.

Devletlerin öğrenme biçimini analiz ettiğimizde, kurumsal, siyasi ve psikolojik süreçlerin karmaşıklıklarını göz önünde bulundurmalıyız. Siyaset ile alakalı öğrenme kurumsal olduğu kadar, psikolojik bir olgudur. Sosyal yapıdaki ve siyasi güçteki geçişler kimin öğrenmesinin önemli olduğunu belirler. Dahası, eğer önceki grup tarafından öğrenilen dersler devam ettirilecekse, örgütlerin kurumsal hafızaları ve kamulaştırma süreçleri olmak zorundadır. Farklı elit zümrelerin devletin amaç ve araçları ile uluslararası rejimin fırsat ve kısıtlarını nasıl algılamakta ve yeniden tanımlamakta oldukları sorusu, araştırma için son derece önemlidir. Neden Otto von Bismarck, İmparator Wilhelm ve Adolf Hitler Almanya için birbirlerinden farklı fırsat ve çıkarlar tanımlamışlardır? Neden Başkan Wilson ve Coolidge Amerika’nın Avrupa'daki çıkarlarını farklı görmüşlerdir ve neden Franklin D. Roosevelt bu meseleyi 1940'da ya da 1936'da, 1933'dekinden farklı yorumlamıştır? Çıkarlar ne ölçüde sistemsel ve yerel değişimler yüzünden farklı tanımlanmaktadır? Çıkarlar lider değişimi ve onları destekleyen koalisyonlar değiştiğinde, ya da iktidardaki kişiler değiştiğinde ne kadar yeniden tanımlanmaktadır? İkinci durumda, yenilikçi teorilerde bahsedilen ulusötesi etkileşimler ve koalisyonlar ne ölçüde gözlemlediğimiz öğrenme sürecine katkı sağlamaktadır?

Gelecek araştırmalar için anahtar soru uluslararası siyasi süreçlerin öğrenme üzerindeki etkisidir. Bazı öğrenmeler devamlı ve süreklidir. Sürekli öğrenme, bürokrasiler ve elitler bazı yaklaşımların diğerlerinden daha iyi işlediğini öğrendiklerinde meydana gelir. Uluslararası rejimler muhtemelen sürekli öğrenmede bazı düzenlemelerden dolayı önemli rol oynamaktadırlar: 1)ulusal bürokrasilerde standart işlev sürecini değiştirme; 2)ulus-altı aktörler için yeni koalisyon firsatları sunma ve üçünü taraflara daha çok ulaşma; 3)kurumlar aracılığıyla katılımcıların davranışlarını değiştirme; 4)diğerlerinin davranışlarını öğrenmeyi kolaylaştıran kurallara uygunluk hakkında bilgi akışı sağlama; 5)bir sorunu diğerinden ayırmaya yardım ederek uzman arabulucularla öğrenmeyi kolaylaştırma. Bunun aksine bazı öğrenmeler ise Münih, Büyük Buhran ya da Afganistan’ın işgali gibi devamlılık arz etmeyen olaylar ya da krizler sonucu öğrenilir. Krizden doğan öğrenmeler bile kurumlar tarafından kolaylaştırılabilir; bu kurumlar uluslararası rejimleri, yerel siyasi partileri ve bürokrasileri içerebilir. Devletler, devlet ve uluslararası sekreterlikler arasında uluslararası rejimler tarafindan sağlanan bağlantı büyük olaylar hakkında ortak bir izahatın yayılmasına yardımcı olabilir. Bu sebeple, öğrenme ister sürekli ister devamlılık arz etmeyen cinsten olsun, rejimler kurumsal hafıza yaratma, değiştirme ya da güçlendirmede rol oynayabilir. Rejimlerin ilkeleri ve normları önemli çevrelerce içselleştirilip, bilgiyi elekten geçiren inanç sisteminin parçası olabilirler; bu rejimlerin kendileri devlette sebep-sonuç ilişkisini gören önemli kişilerin görüşlerini değiştiren bilgiyi sağlayabilirler.

İşbirliği, rejimler hatta açık müzakere olmadan da gerçekleşebilir. Axelrod'un belirttiği gibi, aktörler diğerlerinin stratejilerine cevaben öz çıkarlarını tanımladıkça (ve yeni strateji tercih ettikçe) işbirliği gelişecektir. Ayrıca, kuralların ve kurumların öğrenmeyi destekleyeceğinin ya da ilişkinin bir tarafında destekleseler bile öğrenmenin diğer alanlara yayılacağının herhangi bir garantisi yoktur. Fakat rejimler açısından uluslararası politikaya bakış, araştırma için zengin yollar ve geleneksel yaklaşımlarla ele alınmayan önemli sorular akla getirmez. Neden öğrenme bazı alanlarda daha hızlı, bazılarında daha yavaştır? Öğrenme ne zaman uluslararası rejimler gibi kurumların gelişmesine katkıda bulunmuş, ne zaman bulunmamıştır? Bu kurumlar nasıl değişimlere yol açmaktadır? İç faktörler uluslararası rejimler 
aracılığı ile öğrenmeyi hangi ölçüde kolaylaştırmakta ya da zorlaştırmaktadır? Toplumlar, krizleri yeni rejimler yaratarak öğrenmeyi kurumsallaştırabilmek için fırsata dönüştürebilirler mi ${ }^{53} \mathrm{Bu}$ soruların cevaplarını, önemli olmalarına rağmen, henüz bilmiyoruz.

\section{Sonuç}

Bize göre Güç ve Karşılıklı Bağımlılık tarafindan sunulan bu araştırma programı son derece verimlidir. Diğerleri gibi biz de abartı, basmakalıp karşıt görüşler ve kendi teorilerimiz ve kanıtlarımızın muğlaklığı ile suçlansak da, geliştirmeye çalıştığımız araştırma programı gelecek çalışmalar için yararlıdır. Bugün karşılıklı bağımlılı̆̆ı siyasi ve ekonomik bir olgu olarak analiz etmek ve konu-alanı odaklı karşılıklı bağımlılık modellerini incelemek yerleşik bir yaklaşım haline gelmiştir. Siyaset bilimciler tarafından kullanılan müzakere ve bağlantı kavramları bağlamsal farklılıklar ve güç kaynaklarının kısıtlı ikamesi konularında artık daha hassas ve gelişmiştir. Uluslararası rejimler kavram, dünya siyaseti hakkındaki kurallar ve kurumların oluşumu ve bir ölçüde de bu kurallar ve kurumların devlet davranışları üzerindeki etkileri gibi araştırma konularını teşvik etmiştir.

$\mathrm{Bu}$ araştırma programında başarılar kadar hatalar da vardır. Öğrenme teorisi olmadan rejimlerdeki ve devlet politikalarındaki değişimleri anlamak zor görünmektedir; fakat öğrenme kavramı belirsizliğini korumaktadır ve kimse uluslararası siyasette tutarlı bir öğrenme teorisi geliştirmemiştir. Ayrıca, sentez girişimimizin liberal kısmı ile gerçekçi tarafa nazaran daha az ilgilenilmiştir. Dünya siyasetinde süreç ve yapının kapsamlı ve sistemsel analizine sadece liberallerin kurumlar, karşılıklı bağımlılık ve düzenli sınır ötesi bağlantılara yaptıkları vurguları kısmen kattık. Karmaşık karşılıklı bağımlılık kavramı yanlış anlaşıldı ya da atlanıldı; bu konuda özellikle iç ve uluslararası süreçler bileşiminin tercihleri nasıl şekillendirdiğine yeteri kadar ilgi göstermedik. İç politikaya daha fazla ilgi gösterilmesi gerekliliği ve bunun uluslararası siyaset ile bağlantısı sadece sistemsel seviyede yürütülen araştırmanın veriminin azaldığı şeklinde bir inanışa yol açtı.

Şimdi, yapıyı ve yapının sürecini içerecek şekilde, uluslararası sistemin kısıtlamaları ve fırsatları arasındaki etkileşim ile devletlerin içindeki başat aktörlerin çıkar algılarına odaklanmalıyız. Uluslararası kurumların gelişiminin, birey ve grup öğrenmelerinin ya da yerel siyasetin değişiminin sonucunda öz çıkar kavramının nasıl değiştiğini incelemeliyiz. Bu çaba, detaylı ampirik araştırma ile destekli dinamik bir analiz gerektirmektedir ve uluslararası ilişkiler ve karşılaştırmalı siyaset arasındaki sınırların daha fazla bulanıklaşmasına sebep olacaktır. Zorluklara gögüs gerebilecekler için, gelecek on yıl akademik anlamda heyecan verici bir dönem olabilir.

53 Böyle bir argüman ileri görüşlü siyaset yapıcıların amacı olmalıdır. Bakınız Robert O. Keohane and Joseph S. Nye, Jr., “Two Cheers for Multilateralism”, Foreign Policy, Cilt 61, 1985. 


\section{Kaynakça}

Aggarwal, Vinod K, Liberal Protectionism: The International Politics of Organized Textile Trade, Berkeley, University of California Press, 1985.

Art, Robert J.,“To What Ends Military Power?”, International Security, Cilt 4, No 4, 1980, s.3-35.

Axelrod, Robert ve Robert O. Keohane, "Achieving Cooperation under Anarchy: Strategies and Institutions", World Politics, Cilt 39, No.1, 1986, s.226-254.

Baldwin, David A., "Power Analysis and World Politics: New Trends Versus Old Tendencies", World Politics, Cilt 31, No.2, 1979, s.169-181.

Baldwin, David A., “Interdependence and Power: A Conceptual Analysis”, International Organization, Cilt 34, No 4, 1980, s.471-596.

Brown, Seyom., New Forces in World Politics, Washington, D.C., Brookings Institution, 1974.

Butler, William L., "The Legal Regime of Russian Territorial Waters”, The American Journal of International Law, cilt 62, No. 1, 1968, s. 51-77.

Buzan, Barry, People, States and Fear, Chapel Hill, University of North Carolina Press, 1983.

Cafruny, Alan W., “The Political Economy of International Shipping: Europe versus America”, International Organization, Cilt 39, No 1, 1985, s. 79-119.

Chayes, Abram, The Cuban Missile Crisis and the Rule of Law, New York, Oxford

University Press, 1974.

Cooper, Richard N., "Prolegomena to the Choice of International Monetary System", International Organizations, Cilt 29, No.1, 1975, s.63-97.

Etheredge, Llyod, “Government Learning: An Overview" Samuel Long (der.), Handbook of Political Behavior, Cilt 2, New York, Plenum Press, 1981, s. 73-161.

Etheredge, Llyod, Can Governments Learn?, New York, Pergamon Press, 1985.

Finifter, Ada (der.), Political Science: The State of Discipline, Washington, D.C., American Political Science Association, 1983.

George, Alexander L., "Case Studies and Theory Development: The Method of Structured, Focused Comparison”, Paul Gordon Lauren (der.), Diplomacy: New Approaches in York, Free Press, 1979, s. 43-68.

George, Alexander L. ve Timothy J. McKeown, "Case Studies and Theories of Organizational Decision Making", Advances in Information Processing in $\quad$ Organizations, Cilt 2, 1985, s. 21-58.

Gourevitch, Peter A., “The Second Image Reversed”, International Organization, Cilt 32, No.4, 1978, s.881-912.

Gourevitch, Peter A., Politics in Hard Times, Ithaca, N.Y., Cornell University Press, 1986.

Gowa, Joanne, Closing the Gold Window: Domestic Politics and the End of Bretton Woods, Ithaca, N.Y., Cornell University Press, 1983.

Haas, Ernst B., "Why We Still Need the United Nations: The Collective Management of International Conflict, 1945-1984”, Policy Paper in International Affairs, No 26, Berkeley, Institute of International Studies, 1986.

Haas, Ernst B., “Why Collaborate? Issue-Linkage and International Regimes”, World Politics, Cilt 32, No 3, 1980, s.357-402.

Haggard, Stephan ve Beth Simmons, “Theories of International Regimes”, International Organization, Cilt 41, No 3, 1987, s.491-517.

Harris, Leo J., "Diplomatic Privileges and Immunities: A New Regime is Soon to be Adopted by the United States", The American Journal of International Law, Cilt 62, 1968, s.98-113.

Hirschman, Albert, National Power and Structure of Foreign Trade, Berkley, University of California Press, 1945.

Holsti, K. J., “A New International Politics?”, International Organization, Cilt 32, No 2, 1978, s.513-530. 
Holsti, K. J., The Dividing Discipline: Hegemony and Diversity in International Theory, Winchester, Mass., Allen\& Unwin, 1985.

Jervis, Robert, Perception and Misperception in International Politics, Princeton, N.J., Princeton University Press, 1976.

Jonsson, Christer, "Sphere of Flying: The Politics of International Aviation", International Organization, Cilt 35, No 2, 1981, s. 273-302.

Katzenstein, Peter J., (der.) Between Power and Plenty: Foreign Economic Policies of Advanced Industrialized States, Madison, University of Wisconsin Press, 1978.

Katzenstein, Peter J., Small States in World Markets, Ithaca, N.Y., Cornell University Press, 1985.

Oye, Kenneth A., Donald Rothchild ve Robert J. Lieber, Eagle Entangled: U.S. Foreign Policy in a Complex World, New York, Longman, 1979.

Keohane, Robert O., “The Demand for International Regimes”, International Organization, Cilt 36, No 2, 1982, s. 325-355.

Keohane, Robert O. "Theory of World Politics: Structural Realism and Beyond”, R. Keohane (der.), Neorealism and its Critics, New York, Columbia University Press, 1986, s.158-203.

Keohane, Robert O., After Hegemony: Cooperation and Discourse in the World Political Economy, Princeton, N.J., Princeton University Press, 1984.

Keohane, Robert O. ve Joseph S. Nye (der.), Transnational Relations and World Politics, Cambridge, Harvard University Press, 1972.

Keohane, Robert O. ve Joseph S. Nye, “Transgovernmental Relations and International Organizations”, World Politics, Cilt 27, No 1, 1974, s. 39-62.

Keohane, Robert O. ve Joseph S. Nye, Jr. “Two Cheers for Multilateralism”, Foreign Policy, Cilt 61, 1985.

Keohane, Robert O. ve Joseph S. Nye, "International Interdependence and Integation”, Fred I. Greenstein and Nelson W. Polsby (der.), Handbook of Political Science, Cilt 8, Reading, Mass., Addison-Wesley, 1975, s. 363-414.

Keohane, Robert O. ve Joseph S. Nye, Power and Interdependence, Boston, Little, $\quad$ Brown, 1977.

Kindleberger, Charles (der.), The International Cooperation, Cambridge, Mass., MIT Press, 1970.

Krasner, Stephen D., "Regimes and the Limits of Realism: Regimes as Autonomous Variables", Krasner (der.), International Regimes, New York, Cornell University Press, 1983, s. 355-368.

Krasner, Stephen D., Structural Conflict: The Third World Against Global Liberalism, Berkeley, University of California Press, 1985.

Leive, David M., International Regulatory Regimes, Lexington, Mass., D.C. Heath, Lexington Books, 1976.

Lipson, Charles, "The International Organization of Third World Debt”, International Organization, Cilt 35, No 4, 1981, s.603-631.

Lipson, Charles, Standing Guard: Protecting Foreign Capital in the Nineteenth and Twentieth Centuries, Berkeley, University of California Press, 1985.

Maghroori, Ray ve Ramberg, Bennett (der.), Globalism Versus Realism: International Relations' Third Debate, Boulder, Westview Press, 1982.

Mansbach, Richard W. ve Johan A. Vasquez, Search of Theory: A New Paradigm for Global Politics, New York, Columbia University Press, 1981.

Michalak, Stanley J., “Theoretical Perspectives for Understanding International Interdependence”, World Politics, Cilt 32, No 1, 1979, s. 136-150.

Moore, John Norton, "The Regime of Straits and the Third United Nations Conference on the Law of Sea", cilt 74, 1980, s. 77-121.

Neustadt, Richard ve Ernest May, Thinking in Time, New York, Free Press, 1986. 
Nye, Joseph S., "Maintaining a Non- Proliferation Regime”, International Organization, Cilt 35, No 1, 1981, s. $15-38$.

Nye, Joseph S., "Nuclear Learning and U.S.-Soviet Security Regimes," International Organization, Cilt 41, No 3, 1987, s. 371-402.

Odell, John S., U. S. International Monetary Policy: Markets, Power and Ideas as Sources of Change, Princeton, N.J., Princeton University Press, 1982.

Oppenheim, L., International Law, New York, Longmans, Green, 1937.

Peterson, M. J. "Antarctica: The Last Great Land Rush on Earth", International No 3, 1980, s.377-403.

Reisman, W. Micheal, “The Regime of Straits and National Security: An Appraisal of International Lawmaking", The American Journal of International Law, Cilt 74, 1980, s. 48-76.

Rochester, J. Martin. “The Rise and Fall of International Organization as a Field of Study," International Organization, Cilt 40, No 4, 1986, s. 777-813.

Ruggie, John Gerard. "Continuity and Transformation in the World Polity: Toward a Neorealist Synthesis", World Politics, Cilt 35, No 2, 1983, s. 261-85.

Ruggie, John Gerard. “International Responses to Technology: Concepts and Trends”, International Organizations, Cilt 29, No 3, 1975, s. 557-583.

Schelling, Thomas. The Strategy of Conflict, New York, Oxford University Press, 1960.

Schroeder, Paul W. "The 19th Century International System: Changes in the Structure” World Politics, Cilt 39, No 1, 1986, s.1-26.

Sciolino, Elanie. "Gorbachev Favors Atom Safety Code” New York Times, 4 Haziran 1986, s. A12.

Sebenius, James. “Negotiation Arithmetic”, International Organization, Cilt 37, No.2, 1983, s.281-316.

Sebenius, James. Negotiating the Law of the Sea, Cambridge, Harvard University Press, 1984.

Smith, Roger K. “The Non-Proliferation Regime and International Relations”, International Organization, Cilt 41, No 2, 1987, s.253-282.

Smith, Roger K. "Explaining the Non-Proliferation Regime: Anomalies for Contemporary International Relations Theory”, International Organization, Cilt 41, No 2, 1987, s.253-281.

Stein, Arthur A. "The Politcs of Linkage”, World Politics, Cilt 33, No 1, 1980, s. 62-81.

Stein, Janice G. "Detection and Defection: Security 'Regimes' and the Management of International Conflict”, International Journal, Cilt 40, No 4, 1985, s. 599-627.

Steinbruner, John D. The Cybernetic Theory of Decision, Princeton, N.J., Princeton University Press, 1974.

Susan Strange, "Cave! Hic Dragones: A Critique of Regime Analysis”, International Organization, Cilt 36, No 2, 1982, s.419-496.

Tollison, Robert ve Thomas Willett. "An Economic Theory of Mutually Advantageous Issue Linkage in International Negotiations", International Organization, Cilt 33, No.4, 1979, s.425-49.

Vasquez, John A. ve Richard W. Mansbach. “The Issue Cycle and Global Change”, International Organization, Cilt 37, No 2, 1983, s. 257-79.

Vernon, Raymond. “Sovereignty at Bay Ten Years After,” International Organization, Cilt 35, No.3, 1981, s. $517-$ 530.

Visscher, Fernand. Le Regime Nouveau des Détroits, Brussels, Belinfante Frères, 1924.

Wagner, Harrison. "Economic Interdependence, Bargaining Power and Political Influence," basılmamış makale, Austin, University of Texas, 1986.

Waltz, Kenneth N. “Response to My Critics," Keohane (der.), Neorealism and Its Critics, s. 322-346.

Waltz, Kenneth N. Theory of International Politics, Reading, Mass., Addison-Wesley, 1979. 
Yoffie, David. Power and Protectionism: Strategies of the Newly Industrializing Countries, New York, Columbia University Press, 1983.

Young, Oran R. Compliance and Public Authority, Washington, D.C., Institute for the Future, 1979.

Young, Richard. "The Legal Regime of the Deep-Sea Floor", The American Journal of International Law, cilt 62, No. 3, 1968, s.641-53.

Zacher, Mark W. “Trade Gaps, Analytical Gaps: Regime Analysis and International Commodity Trade Regulation", International Organization, Cilt 41, No 2, 1987, s.173-202. 